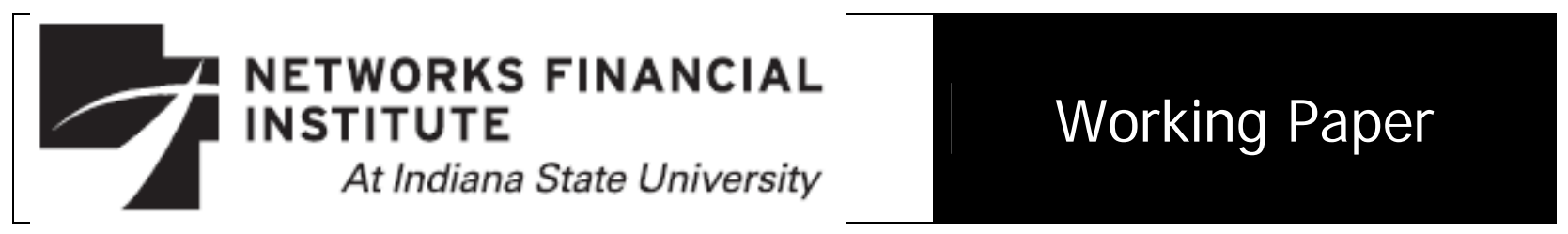

2013-WP-01

February 2013

\title{
The Pronounced I mpact of Macroeconomic Stress on the Financial Sector: I mplications for Real Sector Growth
}

\section{Kabir Hassan and William J. Hippler I I}

\begin{abstract}
The financial sector incurred big losses during the recent financial collapse and recession. The losses occurred despite regulatory requirements imposed upon the financial services industry meant to ensure confidence and stability. This study analyzes the profitability and stock returns of financial sector firms during periods of economic and financial market turbulence. It shows that economic downturns and financial stress have a pronounced impact on financial firms. We find that the increased sensitivity to financial market distress appears to increase with recent trends in the financial services industry such as deregulation, globalization, and financial innovation. Moreover, we determine that the source of the increased sensitivity is likely driven by non-depository institutions, such as finance and investment, but not insurance companies. These results raise the question of whether the current regulatory regime can succeed in ensuring that financial markets are sufficiently stable to service an increasingly complex global economy.
\end{abstract}

About the Authors: Kabir Hassan is a professor at the University of New Orleans. He is a financial economist with consulting, research and teaching experiences in development finance, money and capital markets, corporate finance, investments, monetary economics, macroeconomics and international trade and finance. He has published five books, over 135 articles in refereed academic journals and has presented over 255 research papers at professional conferences globally.

William Hippler is a Ph.D. student in the field of Financial Economics with the Department of Economics and Finance at the University of New Orleans where he is currently teaching for the Department of Economics and Finance. His areas of interest are financial markets and institutions, international diversification, portfolio management, and corporate finance.

Keywords: Financial crises, Financial institutions, Policy, Regulation, Financial markets

JEL classification: G01; G21; H12; G28

The views expressed are those of the individual author and do not necessarily reflect official positions of Networks Financial Institute. Please address questions regarding content to Kabir Hassan at mhassan@uno.edu. Any errors or omissions are the responsibility of the author.

NFI working papers and other publications are available on NFI's website (www. networksfinancialinstitute.org). Click "Thought Leadership" and then "Publications." 


\section{INTRODUCTION}

The stability and efficiency of the financial sector has gained increased importance in light of the recent financial crisis and ensuing "Great Recession". The consequences of the collapse of many financial institutions were not confined to Wall Street. The failure of the financial sector in handling increasing financial stress contributed to a worldwide economic slowdown. As a result, countless investors, pension funds and corporations realized losses in the trillions of dollars, and millions of people became unemployed. The effects of this downturn are still being felt today. Not surprisingly, there has been an increased focus on the financial sector, as stakeholders around the world study the causes of the crisis and contemplate which solutions, if any, could be employed to prevent similar occurrences in the future.

Efficiently functioning capital markets are paramount to generating and sustaining economic growth, and financial services play an important role in developing and maintaining healthy markets. The consequences of a financial system collapse became apparent in the aftermath of the $2008 \mathrm{Global}$ Financial Crisis. Accordingly, there have been continuing efforts to increase the efficiency and stability of the financial services sector. Since the 1980s, deregulation in U.S. markets and liberalization policies in emerging markets have coincided with a growing degree of international market integration and robust growth in emerging markets. Proponents of the financial reforms that favored open and less restrictive markets may take credit for some of the successes of what seems to be improved international market efficiency and growth. However, the recent financial crisis illustrates that the increasingly integrated and complex financial system appears to carry with it a great deal of risk that may not be fully understood.

The typical financial company holds long-term assets funded with shorter term liabilities. ${ }^{1}$ Accordingly, the majority of risk in the financial sector stems from the credit risk of borrowers and the price risk of the assets. To avoid excess losses from either of these sources, financial companies have

\footnotetext{
${ }^{1}$ While, in general, this is true, there may be differences among the financial service industries. Traditional commercial banks certainly experience this asset maturity mismatch, while other financial companies such as insurance firms may not. Thus, the sensitivity to macroeconomic stress and the motivation to engage in complicated risk management strategies may vary across financial firms. Thus, a secondary goal of this paper is to provide a more in depth look within the financial sector in order to determine which types of financial firms contribute to the financial sector risk shown in this paper.
} 
increasingly relied on derivative securities to hedge their asset portfolios. Additionally, the financial services industry has faced an increasingly friendly regulatory environment for the designing and implementation of derivative securities. On one hand, the use of derivatives allows financial services companies to transfer risk and insure against both default and price risk, resulting in less uncertainty in the capital markets. On the other hand, the trading in redundant securities may not lead to any economic benefits. In addition, the difficulty in pricing complex derivatives may add yet another level of unanticipated risk to a financial institution's balance sheet.

This paper focuses on the impact of macroeconomic shocks and financial market stress on the financial services sector. The translation of macroeconomic events into corporate earnings or asset price appreciation (depreciation) is a complex and dynamic process. However, we use previous studies as a guide to building an empirical model that generalizes that process. Through the use of panel data techniques, we use both firm-specific and macroeconomic data to study the degree to which the financial services sector is sensitive to macroeconomic distress. Throughout the analysis, we place a particular emphasis on insurance companies. We show how insurance companies are affected by financial distress and compare their sensitivity to other industries within the financial services sector.

In light of the results, the fragility of the financial sector seen during the recent financial crisis is not surprising. The results show that financial sector profitability is extremely sensitive to the macroeconomic regime. The average profitability of a financial firm is significantly higher than the average firm in normal economic times. However, the results show that the specific impact of a recession on financial firms can be significantly worse than that of other industries. This has implications for the effectiveness of current risk management techniques used by the finance sector as well as the regulatory bodies charged with ensuring stable markets.

This paper proceeds as follows. In Section 2, we provide a review of the literature regarding the impact of macroeconomic news on firm and stock performance as it relates to financial crises. Section 3 describes the methodology used in the empirical analysis. Section 4 describes data used in the empirical 
models. Section 5 describes the impact of financial distress on financial firm profitability. Section 6 examines the effect of financial distress on stock returns. Section 7 conducts a further examination of the financial services industry. Section 8 discusses robustness issues and areas for future research. Section 9 concludes.

\section{LITERATURE REVIEW}

This paper combines several lines of literature that relate to the causes of economic growth in both the financial and real sectors and how each is affected by economic downturns and financial crises. Past research has attempted to describe the process by which economic fundamentals are transmitted through the financial system and their impact on real and financial sector asset prices and performance. Additionally, much recent literature has focused on the impact of financial market distress in light of increasing international market interdependency. The following review of the literature on these topics illustrates the current state of empirical research.

\subsection{Macroeconomic conditions and interest/exchange rates}

The driving force behind efficiently operating financial markets is the ability of financial intermediaries to properly price and transfer capital to the real economy through the supply and demand for domestic and foreign currencies. As interest and exchange rates adjust to equilibrium, financial intermediaries must adjust their positions to reflect new information imputed into the supply and demand for real capital. In this sense, the essential mechanism upon which the financial sector relies is influenced by the macroeconomic conditions underlying the real economy. This relationship illustrates the importance of identifying the relationship between real economic activity and the supply and demand for capital, and an extensive body of literature has focused on the impact of macroeconomic events on domestic and foreign interest and exchange rates. As the largest economy in the world, economic progress in the United States has been a key driver of global capital demand, and many studies focus on the impact of U.S. macroeconomic news on domestic and sovereign interest and exchange rates. 
Frenkel (1981) examines the effect of "news" on interest and exchange rates in the wake of the establishment of the modern, flexible exchange rate system largely developed in the 1970s. This study finds that macroeconomic news is essential in the determination of foreign exchange and interest rates. ${ }^{2}$ A special emphasis is placed on unanticipated events or "news", because these events are the main theoretical drivers of changes in the cost of borrowing. Important economic events like unexpected inflation are implied to be the type of news that determines the size and direction of the change in interest rates.

More recent studies have extended the literature to more accurately define the relationship between certain types of news and the related effects on the cost of funds. Along similar lines as Frenkel (1981), it is shown that unexpected positive changes in key U.S. macroeconomic variables have an impact on long and short-term interest rates. Measures that reflect underlying economic growth such as retail sales and GDP growth drive up interest rates. Additionally, monetary variables such as inflation and monetary policy stance tend to raise the term structure of interest rates (Faust, et al. (2003)). ${ }^{3}$

Many recent studies also show the impact of U.S. and international fundamental news on foreign exchange rates in the context of emerging markets (Özataya, Özmenb, \&Şahinbeyoğluc (2007), Emir,Özatay, and Şahinbeyoğluc (2005). Neely and Dey (2010) provide a review of the literature showing that macroeconomic news from several major economies influence foreign exchange rates. Unexpected changes in interest rates, employment and output all show a consistent impact on foreign exchange rates. Furthermore, Bellas, Papaioannou, and Petrova (2010) find that financial stress can have a significant impact on sovereign bond yields.

\subsection{Financial sector stock prices and profitability}

\footnotetext{
${ }^{2}$ While "news" in this model is defined as innovations in interest rates, the model is general enough to define "news" as any significant, unanticipated change in a key economic variable that will affect asset prices or cash flows.

${ }^{3}$ Faust, et al. (2003) find that the effect of price "surprises" on interest rates has declined over the period of 1987 to 2002.
} 
Aside from having an impact on overall economic growth, macroeconomic conditions also directly impact the performance of financial intermediaries. Due to the important role of financial intermediaries in matching the supply and demand for money at correct prices, firms in the financial sector are particularly affected by changes in underlying macroeconomic conditions. This fact underscores the importance of a financial firm's ability to anticipate, react to, and hedge against both expected and unexpected changes in real economic production. The literature shows that both idiosyncratic and macroeconomic factors influence financial sector performance. One such line relates to the stock price performance of financial firms, while another relates the performance of financial firms, typically measured by some ratio such as return on assets. Since the durations of financial firm assets are often greater than the durations of liabilities, a change in interest rates will disproportionately affect the value of assets versus liabilities. In this case, an increase in interest rates will drive up the value of assets and lower the value of common equity. This simple relationship illustrates the impact of interest rate changes on the performance of financial sector stock returns.

The effect of interest rate changes on the stock price performance of financial firms is tested empirically by Flannery and James (1984). They find that the common stock returns of financial companies are associated with unanticipated changes in key interest rates. The positive coefficient between unanticipated interest rate changes and the return on bank stock indexes is consistent with the idea that the decrease in equity capital caused by maturity mismatch increases the investor's required return. An alternative explanation is that increased interest rates are also associated with the contracting monetary policies indicative of good overall economic performance. Flannery and James (1984) find a link between of the magnitude of this affect and the maturity mismatch of assets and liabilities that tend to occur in the financial sector. Claire and Courtenay (2002) also show that changes in interest rate policy and monetary actions are incorporated into financial contract prices. ${ }^{4}$ Staikouras (2005) extends similar results to the sample of U.K. firms. Additionally, Bernoth and Pick (2011) find that the long-term rate of

\footnotetext{
${ }^{4}$ They show, however, that the announcement effect has weakened over time.
} 
interest is consistently found to be an important factor in distance to default for both banks and insurance companies.

Interest rates and exchange rates are not the only macroeconomic factors found to significantly affect financial firm performance. While changes in interest and exchange rates can be reflections of underlying economic conditions, economic growth can have a more direct and distinctive impact on financial firm performance. Changes in interest rates impact financial firm performance through the duration gap, but overall economic growth can affect the general supply and demand for loanable funds. Healthy economic growth tends to increase both the supply and demand for positive net present value (NPV) projects and reduces the risk of default. Other macroeconomic variables have been found to empirically impact the performance and returns of financial companies.

Ewing (2002) develops an impulse response model to measure the sensitivity of the NASDAQ Financial 100 to changes in key macroeconomic variables. The model includes four key macroeconomic drivers of financial stock performance: real output, consumer prices, monetary policy stance, and default risk. The authors use the Fed Funds rate as a proxy for monetary policy position, the spread between Baa and Aaa bonds as a measure of default risk and the Consumer Price Index as a measure of consumer prices. Williams (2003) also shows that return on assets is associated with GDP growth. Athanasoglou, Brissimis, and Delis (2005) find that business cycle effects and inflation are important determinants of bank profits as well. Bernoth and Pick (2011) extend their study to include both banks and insurance companies with a model that includes the long term bond rate, inflation, industrial production growth, domestic credit growth, equity market growth, exchange rate growth, unemployment, GDP growth, the P/E ratio of the stock market, the implied volatility of S\&P 500 index options referred to as VIX, the degree of capital openness and the degree of financial openness.

A final piece in accurately modeling the cross-section of financial firm performance is firm-specific or idiosyncratic factors. While macroeconomic conditions like GDP and inflation affect the overall business environment in which financial firms operate, the decisions of management can influence how well the 
bank is able to anticipate and take advantage of the external economic conditions. Individual firm decisions like capital structure and payout policy can affect the firm's ability to operate efficiently in a given economy. Hoffman (2011) finds that a higher capital ratio is associated with lower profitability and the size of the firm measured by the log of assets. Bernoth and Pick (2011) also use firm-specific variables such as the growth rate of dividends and retained earnings.

The literature relating to the profitability and stock returns for financial sector firms presents several theoretical motivations for both macroeconomic and firm-specific factors in determining profitability and stock return. The empirical results throughout the world show strong evidence that these effects are significant in the observed data. Accordingly, many researchers incorporate both effects into the model of bank profitability. Athanasoglou, Brissimis, and Delis (2005) model bank profitability as a function of firm-specific, industry-specific and macroeconomic factors.

\subsection{Macroeconomic news and stock returns}

The literature also documents a similar relationship between macroeconomic fundamentals and the performance of firms in the real economy. Chen, Roll and Ross (1986) find that the long and short-term interest rate spread, inflation, industrial production and high-low grade bond spread have an important impact on the performance of NYSE stocks. ${ }^{5}$ Their findings notably show a positive relationship in stock price reactions to changes in industrial production as well as increases in the risk premium, as traditional financial theories suggest. Their results also show that these macroeconomic variables carry predictive power beyond that of a market index such as the S\&P 500.

Fama (1990) concludes that nearly half of the return variance of NYSE stocks is explained by variables intended to measure macroeconomic growth prospects. Schwert (1990) extends the Fama (1990) results to include data ranging from 1889 to 1988 . Their extension shows the persistent effect of anticipated economic fundamentals on real sector stock returns. The consistent finding over such a long sample period makes it unlikely that the results are a product of sample selection.

\footnotetext{
${ }^{5}$ They do not find that consumption has much explanatory power.
} 
McQueen and Roley (1993) do not ascribe the same direct link between macroeconomic news and daily stock returns, and point to other studies that show daily asset prices seem unresponsive to most macroeconomic news. However, they do find a relationship between daily returns and economic news when significant macroeconomic events like the position within the business cycle are taken into account. They find a very state-dependent relationship between economic news and stock prices. Stock prices react positively to positive economic news when the economy is weak, but the relationship is reversed when the economy is experiencing growth. State-invariant discount rates are one explanation as to why this relationship is observed.

More recently, Funke and Matsuda (2006) study the impact of macroeconomic events on the stock returns of U.S. and German stocks. Similar to Ewing (2002), there are several categories of news events the authors expect to have a significant impact on stock prices. They use current data relating to the state of the economy, such as growth in the gross domestic product. Secondly, they use supposed leading indicators of economic activity such as consumer confidence indices. They also use measures of interest rates and prices. The main findings of the paper suggest that monetary policy news such as consumer prices and interest rates have the largest impact on real stock price movements. In addition, similar to McQueen and Roley (1993), they also find evidence of some asymmetric reaction of the stock market to certain types of news, conditional upon the state of the economy. For example, the authors find that real economic news has a larger impact on stock prices during times of recession than in expansionary periods.

Flannery and Protopapadakis (2002) also look at the impact of macroeconomic events and stock returns. The authors use a GARCH methodology with daily observations. Several of the macroeconomic variables included in the model are data on real GDP, retail sales, consumer spending, consumer income, prices, money supply, housing starts/sales, employment and trade balance. The authors find that several inflation measures, including the CPI, balance of trade, unemployment, and money supply, significantly affect aggregate stock returns. 


\subsection{Financial crisis, contagion, and the real economy}

There is also a line of literature that establishes the relationship between financial crises and recessions and the performance of financial and real sector firms. Several studies look at the effects of the Asian crisis on financial firm performance. Kutan, Muradoglu, and Sudjana (2012) look at IMF news and the impact on the real and financial sectors during the Asian crisis. They find that IMF news affects the returns of the financial sector significantly, but that the real sector economy was less responsive. Borensztein and Lee (2002) show that profitability was a key factor in the ability of financial sector firms to access credit during the Korean credit crisis. Sufian and Habibullah (2010) focus on the performance of Indonesian banks during the Indonesian financial crisis. They utilize a panel data model, and the main dependent performance variable in their model is Return on Assets (ROA). The reasoning behind this is quite intuitive, as a key goal of a bank is to maximize the use of its assets. Another bank-specific measure used in this study is the size of the bank. Naturally, external factors affecting bank profitability are also included. They include measures of economic growth such as GDP, bank asset concentration and crisis dummy variables. One of the main findings is that larger banks tend to make lower profits. Not surprisingly, they find that financial crises have a significantly downward impact on bank performance.

There is also a growing literature examining the effects of the recent global recession. Recent evidence from the Global Financial Crisis of 2007-2009 shows the increasing impact of financial market failures on the real economies across the world. Virtually no economy or sector was spared the reach of the recent recession (Baur (2011)). ${ }^{6}$ Bernoth and Pick (2011) point out the importance of the inter-linkages between firms in the financial sector. The links not only between banks, but between banks and other financial firms such as insurance companies, have a significant impact on the systemic risk of the global financial system.

Bolt et al. (2010) look at bank profitability in light of the recent 2008 financial crisis. They find a procyclical link between bank profits and the economy. However, they find that the relationship is nonlinear

${ }^{6}$ Baur (2011) shows that the Healthcare, Telecommunications, and Technology sectors were relatively less affected by the recent Global Financial Crisis. 
in that severe recessions have a pronounced impact on bank profitability. They argue that higher-thanexpected asset value and loan losses account for this affect. Dietrich and Wanzenried (2010) look at Swiss banks during the recent crisis and find that better capitalized banks tend to be more profitable. They do not find a significant relation between bank profitability and GDP, but do find that stock market capitalization and the term structure of interest rates are important.

The cyclical nature of bank profits may be exacerbated by current banking regulatory paradigms as well as the increased interdependence of the global financial system (Blejer (2006)). Specifically, Nijskens and Wagner (2011) document a significant increase in financial stock betas with the advent of new methods of transferring credit risk such as mortgage backed securities, credit default swaps (CDSs) and collateralized loan obligations (CLOs). These instruments essentially transfer credit risk from individual lenders to the financial system. 
The increased betas may be a reflection of the market's anticipation of the increased risk inherent in the financial system due to the use of these new securities, some of which pose significant off balance sheet risk. They also point to the possible need for more comprehensive regulations that take into account an institution's impact on systemic risk.

\section{METHODOLOGY}

The main goal of this paper is to compare the degree to which financial and non-financial firms are affected by macroeconomic shocks and financial crises. We expect all firms to be significantly affected by economic slowdowns and credit crises. However, their impact on financial firms is of particular importance, since a stagnant financial sector can have dramatic real sector implications. We seek to develop a framework that compares the impact of financial distress on firm performance. The degree to which the financial sector firms differ from non-financial firms has important policy implications as well.

As part of this framework, we first present an analysis that examines the impact of macroeconomic shocks on firm profitability in Section 5. As part of this initial analysis, we present a univariate analysis to examine the impact of a macroeconomic recession on several key firm fundamentals. We compare the level differences caused by a recession between financial and non-financial firms. We follow this comparison with a series of multivariate regression models that attempt to more accurately define the role that financial shocks play in firm profitability. Our baseline multivariate model is along the lines of Sufian and Habibullah (2010). We use a panel data model of the general form:

$$
\text { Profitability }=\alpha+\beta^{\prime} \text { Firmspecific }+\gamma^{\prime} \text { Macroeconomic }+\theta^{\prime} \text { Distress }+\varepsilon
$$

A fixed-effects estimation procedure is employed to allow for significant cross-sectional differences among firms. A test for different intercepts rejects the hypothesis of a pooled panel data approach at the one percent level. Additionally, a series of Hausman tests show that a random effects estimation procedure is likely inappropriate for the models. 
In our baseline model, we assume that firm performance is a function of several key firm-specific and macroeconomic determinants. The firm-specific factors included in the model are total assets, the debt ratio and a lagged profitability measure: profit margin. The macroeconomic factors include inflation measured by the CPI for all urban consumers, real GDP growth, the Fed Funds rate, the spread between the Fed Funds rate and the 10-year Treasury bond and a set of quarterly dummy variables. We also include a set of distress or crisis variables, namely a recession dummy variable and the Federal Reserve's Financial Condition Index. It is the sign and significance of these two variables and their interactions with firm-specific variables that drive many of the conclusions in this paper.

In Section 6, we extend the analysis to the cross-section of stock returns. We assume that if the firm profitability model presented in Section $\mathbf{5}$ is correctly specified, then the influence of the deterministic factors should also be significant in explaining the cross-section of stock returns. However, we do expect the results to be somewhat weaker since the market should be able to more efficiently price fundamental risk. We use the same panel data methodology described above.

Finally, in Section 7, we conclude our analysis with a more detailed accounting of the financial firm results. In this section, we use SIC codes to divide the financial firms into six sub-categories: depository institutions, finance companies, financial services, insurance, real estate, and investment companies. We apply our multivariate, panel data regression framework to examine how different types of financial institutions react to financial stress. We compare the results of the same regressions for different types of financial institutions. In addition, we utilize a set of industry interaction dummy variables to directly compare the effects across the sub-sectors in a nested model. Here, we can directly examine the signs and significance of the coefficients.

\section{THE DATA}

Following the literature, we collect data on the variables commonly found to be associated with the profitability and stock performance of financial firms. As in Sufian and Habibullah (2010) and others, we include both firm-specific data as well as macroeconomic variables. 
All firm-level data is collected from COMPUSTAT. These data include information on firm size, profitability and leverage. Likewise, all macroeconomic time series data are collected from the St. Louis Federal Reserve's FRED database. These data include real gross domestic product growth, inflation measured by the Consumer Price Index (CPI), the Fed Funds interest rate and the rate on the tenyear U.S. constant-maturity Treasury bond. Also included are measures that proxy for macroeconomic and financial crises. A dummy variable indicates whether the given observation falls under an NBER-defined recession. The Federal Reserve's National Financial Conditions Index (NFCI) measures the overall financial status of the economy. This index includes conditions in the overall economy, but also includes factors that represent conditions in the money markets, debt and equity markets, banking system and "shadow" banking system. This index is superior to other financial stress indices due to the length of the time series for which it is available and the depth of markets for which it covers. When the Financial Conditions Index level is above zero, financial markets are tighter than normal, or are under a relatively higher amount of stress. The converse is true for levels below zero.

We filter the firm-level data to reduce the impact of outliers and data errors. All firm-level data are measured quarterly from 1980Q1 through 2010Q4. We require the sample firms to have revenues greater than $\$ 500,000$ and total assets greater than $\$ 1,000,000$. We require that our firm-quarter observations contain the complete set of variables used in our baseline model. For example, an observation with a missing value for the debt ratio would be excluded. We also require that each sample firm have at least eight quarters of complete data. As a final measure of ensuring a representative sample, we calculate the dependent variable, profit margin, and windsorize the one percent profit margin tails for each year. This has the effect of eliminating many extreme observations that are likely the result of errors in the data.

Our final sample contains 699,211 firm-quarter observations for a sample of 17,591 firms. Table 1 presents some sample statistics for the firms in the sample from COMPUSTAT. Summary statistics are presented for several key variables for the entire sample, each decade, and for each SIC-classification industry. The data show that financial firms average a higher amount of total assets with $\$ 15.9 \mathrm{~B}$, 
compared with the full sample average of $\mathbf{\$ 3 . 6 B}$. Insurance companies show similar characteristics with average total assets of $\mathbf{\$ 1 8 . 8 B}$ over the sample. The variance of total assets is higher for financial firms and insurance companies, however. Financial firms on average also have higher revenues with $\$ 479 \mathrm{M}$ compared with the full sample average of $\$ 430 \mathrm{M}$. Insurance companies, on the other hand, see almost twice the total average revenues of both financial firms and the full sample. The variance of financial firm revenues is lower than that of non-financial firms. Financial firms are able to generate a net income of $\$ 33.7 \mathrm{M}$ on revenues for a profit margin of $\mathbf{7 . 8} \%$, compared with $-\mathbf{2 . 7 \%}$ for non-financial firms. The average insurance company profit margin of $6.1 \%$ is below that of the financial firms. However, the standard deviation of insurance company profitability of $\mathbf{2 . 3 \%}$ is lower than that of financial firms of 3.4\%. Not surprisingly, financial firms and insurance companies have higher average debt ratios than non-financial firms with $62.7 \%, 70.1 \%$ and $51.2 \%$, respectively. Financial firms and insurance companies also exhibit higher average ROE, ROA, retained earnings and cash, but lower capital expenditures and market-to-book ratios.

The dependent variable in our profitability analysis is profit margin. Figure 1 compares the profit margins of financial firms, defined as SIC codes from 6000 to 6999 , with those of non-financial firms and insurance companies, defined as having SIC codes between 6300 and 6500, over the 1980Q1 to 2010 Q4 sample period. The figure shows that financial firm profit margins are consistently higher than those of non-financial firms, as previously shown in Table 1. We also see evidence that profit margins for the insurance industry are slightly below those of other financial firms. The figure also shows a significant amount of seasonality in the data. We incorporate lagged profit margin and quarterly dummy variables in our multivariate regressions to account for this. 
Table 1: Summary

\section{Statistics}

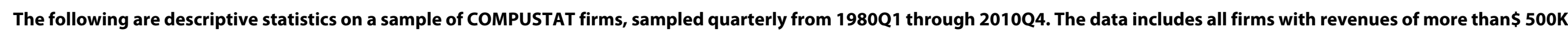
and is windsorized in each tail at the one percentile. The sample also requires each firm to have at least 8 quarters of complete data.

\begin{tabular}{|c|c|c|c|c|c|c|c|c|c|c|c|c|c|c|c|}
\hline & \multirow[b]{2}{*}{$\begin{array}{c}\text { Full } \\
\text { Sample }\end{array}$} & \multirow[b]{2}{*}{$1980 s$} & \multirow[b]{2}{*}{ 1990s } & \multirow[b]{2}{*}{2000 s } & \multirow[b]{2}{*}{$\begin{array}{c}000- \\
999\end{array}$} & \multirow[b]{2}{*}{$\begin{array}{c}1000- \\
1999\end{array}$} & \multirow[b]{2}{*}{$\begin{array}{l}2000- \\
2999\end{array}$} & \multirow[b]{2}{*}{$\begin{array}{c}3000- \\
3999\end{array}$} & \multicolumn{2}{|c|}{ SIC Industry } & \multirow[b]{2}{*}{$\begin{array}{c}6000- \\
6999 \\
\end{array}$} & \multirow[b]{2}{*}{$\begin{array}{c}7000- \\
7999 \\
\end{array}$} & \multirow[b]{2}{*}{$\begin{array}{l}8000- \\
8999\end{array}$} & \multirow[b]{2}{*}{$\begin{array}{l}9000- \\
9999\end{array}$} & \multirow[b]{2}{*}{$\begin{array}{c}\text { Insuranc } \\
\text { e Firms }\end{array}$} \\
\hline & & & & & & & & & $\begin{array}{c}4000- \\
4999\end{array}$ & $\begin{array}{c}5000- \\
5999\end{array}$ & & & & & \\
\hline \multicolumn{16}{|l|}{ Total Assets } \\
\hline Mean & 3610.7 & 1115.2 & 2083.8 & 6711.6 & 751.3 & 1246.5 & 2930.3 & 1510.4 & 4646.5 & 1144.6 & 15941.9 & 814.4 & 483.0 & 12744.0 & 18779.0 \\
\hline & & & & & 1864. & & & & & & & & & & \\
\hline Std. Dev. & 32960.8 & 5010.1 & 13007.6 & 51471.6 & 9 & 4011.2 & 13187.6 & 10793.0 & 12849.9 & 5227.5 & 92453.8 & 4400.4 & 1528.8 & 69986.1 & 92860.2 \\
\hline \multicolumn{16}{|l|}{ Revenue } \\
\hline Mean & 429.7 & 220.4 & 289.8 & 701.4 & 183.8 & 183.2 & 739.5 & 340.0 & 570.2 & 559.2 & 478.8 & 150.7 & 123.3 & 1188.3 & 802.1 \\
\hline Std. Dev. & 2184.4 & 932.5 & 1310.7 & 3185.2 & 390.4 & 578.3 & 3619.9 & 1977.4 & 1579.8 & 2616.2 & 1934.6 & 904.7 & 390.7 & 5126.3 & 2447.0 \\
\hline \multicolumn{16}{|l|}{ Net Income } \\
\hline Mean & 22.8 & 11.2 & 13.6 & 39.4 & 4.8 & 14.5 & 50.7 & 12.2 & 33.9 & 13.2 & 33.7 & 7.6 & 4.3 & 90.6 & 47.7 \\
\hline Std. Dev. & 228.2 & 61.4 & 100.7 & 351.6 & 65.5 & 129.8 & 364.8 & 128.1 & 338.7 & 99.2 & 256.4 & 129.7 & 29.9 & 534.8 & 249.6 \\
\hline \multicolumn{16}{|l|}{ Profit Margin } \\
\hline Mean & -0.027 & 0.030 & -0.017 & -0.074 & -0.055 & -0.030 & -0.077 & -0.039 & 0.018 & 0.001 & 0.078 & -0.096 & -0.043 & -0.120 & 0.061 \\
\hline Std. Dev. & 0.402 & 0.152 & 0.321 & 0.551 & 0.444 & 0.448 & 0.527 & 0.368 & 0.321 & 0.151 & 0.344 & 0.512 & 0.389 & 0.531 & 0.234 \\
\hline \multicolumn{16}{|l|}{$R O A$} \\
\hline Mean & 0.002 & 0.009 & 0.003 & -0.002 & 0.003 & 0.004 & 0.003 & 0.002 & 0.005 & 0.005 & 0.006 & -0.006 & 0.002 & -0.012 & 0.007 \\
\hline Std. Dev. & 0.041 & 0.028 & 0.041 & 0.048 & 0.041 & 0.035 & 0.043 & 0.045 & 0.028 & 0.034 & 0.027 & 0.057 & 0.045 & 0.054 & 0.022 \\
\hline \multicolumn{16}{|l|}{ ROE } \\
\hline Mean & -0.001 & 0.013 & -0.002 & -0.010 & 0.000 & 0.001 & 0.002 & -0.004 & 0.007 & 0.002 & 0.014 & -0.021 & -0.005 & -0.041 & 0.020 \\
\hline Std. Dev. & 0.126 & 0.095 & 0.125 & 0.142 & 0.127 & 0.108 & 0.123 & 0.127 & 0.113 & 0.128 & 0.096 & 0.154 & 0.138 & 0.182 & 0.088 \\
\hline \multicolumn{16}{|l|}{ Debt Ratio } \\
\hline Mean & 0.512 & 0.533 & 0.514 & 0.495 & 0.480 & 0.478 & 0.488 & 0.448 & 0.613 & 0.549 & 0.627 & 0.459 & 0.496 & 0.527 & 0.701 \\
\hline Std. Dev. & 0.224 & 0.203 & 0.227 & 0.232 & 0.232 & 0.207 & 0.210 & 0.217 & 0.163 & 0.200 & 0.253 & 0.231 & 0.218 & 0.229 & 0.202 \\
\hline \multicolumn{16}{|l|}{ Market Cap } \\
\hline Mean & 1844.5 & 513.2 & 1248.0 & 3214.3 & 908.9 & 1233.1 & 3404.3 & 1256.4 & 2871.2 & 1218.0 & 2052.9 & 1294.2 & 531.1 & 7917.1 & 2757.5 \\
\hline & & & & & 4062. & & & & & & & & & & \\
\hline Std. Dev. & 10472.0 & 2190.0 & 7038.2 & 15041.7 & 6 & 4894.9 & 16632.6 & 7112.8 & 9807.3 & 7386.0 & 9201.5 & 10585.9 & 1721.9 & 40647.4 & 9633.7 \\
\hline Market-to-Book R & & & & & & & & & & & & & & & \\
\hline Mean & 1.53 & 1.01 & 1.95 & 1.53 & 1.16 & 1.42 & 1.71 & 1.54 & 1.29 & 1.51 & 1.29 & 1.81 & 1.75 & 1.27 & 1.07 \\
\hline Std. Dev. & 1.20 & 0.27 & 1.38 & 1.20 & 0.59 & 0.90 & 1.47 & 1.10 & 0.68 & 1.52 & 1.06 & 1.44 & 1.22 & 0.76 & 0.44 \\
\hline Capital Expenditu & & & & & & & & & & & & & & & \\
\hline Mean & 82.1 & 39.3 & 55.4 & 125.0 & 19.6 & 99.7 & 124.6 & 52.4 & 242.5 & 44.3 & 62.0 & 32.2 & 15.5 & 224.5 & 25.7 \\
\hline Std. Dev. & 575.7 & 225.3 & 404.8 & 775.6 & 57.4 & 415.0 & 845.4 & 551.8 & 750.4 & 260.7 & 638.1 & 232.5 & 62.2 & 1168.5 & 253.6 \\
\hline Retained Earnings & & & & & & & & & & & & & & & \\
\hline Mean & 407.2 & 213.6 & 250.1 & 683.4 & 60.2 & 224.5 & 917.2 & 271.0 & 403.8 & 280.0 & 718.6 & 71.3 & 51.7 & 2320.8 & 1161.0 \\
\hline Std. Dev. & 3482.9 & 1059.2 & 1434.1 & 5366.2 & 352.0 & 1314.8 & 6433.9 & 2442.5 & 2919.8 & 1742.7 & 3882.9 & 1587.8 & 334.0 & 12032.2 & 3891.4 \\
\hline Cash & & & & & & & & & & & & & & & \\
\hline Mean & 329.5 & 21.8 & 47.1 & 415.6 & 107.0 & 173.2 & 490.5 & 362.9 & 128.5 & 207.3 & 1187.3 & 210.0 & 92.2 & 6361.0 & 1208.3 \\
\hline
\end{tabular}




\section{Figure 1: Firm Profitability}

This figure depicts the average profitability of our sample firms from 1980Q1 to 2010Q4. Average Profit margin (NI/Sales) per quarter for non-financial firms are compared with those of financial firms and insurance companies.

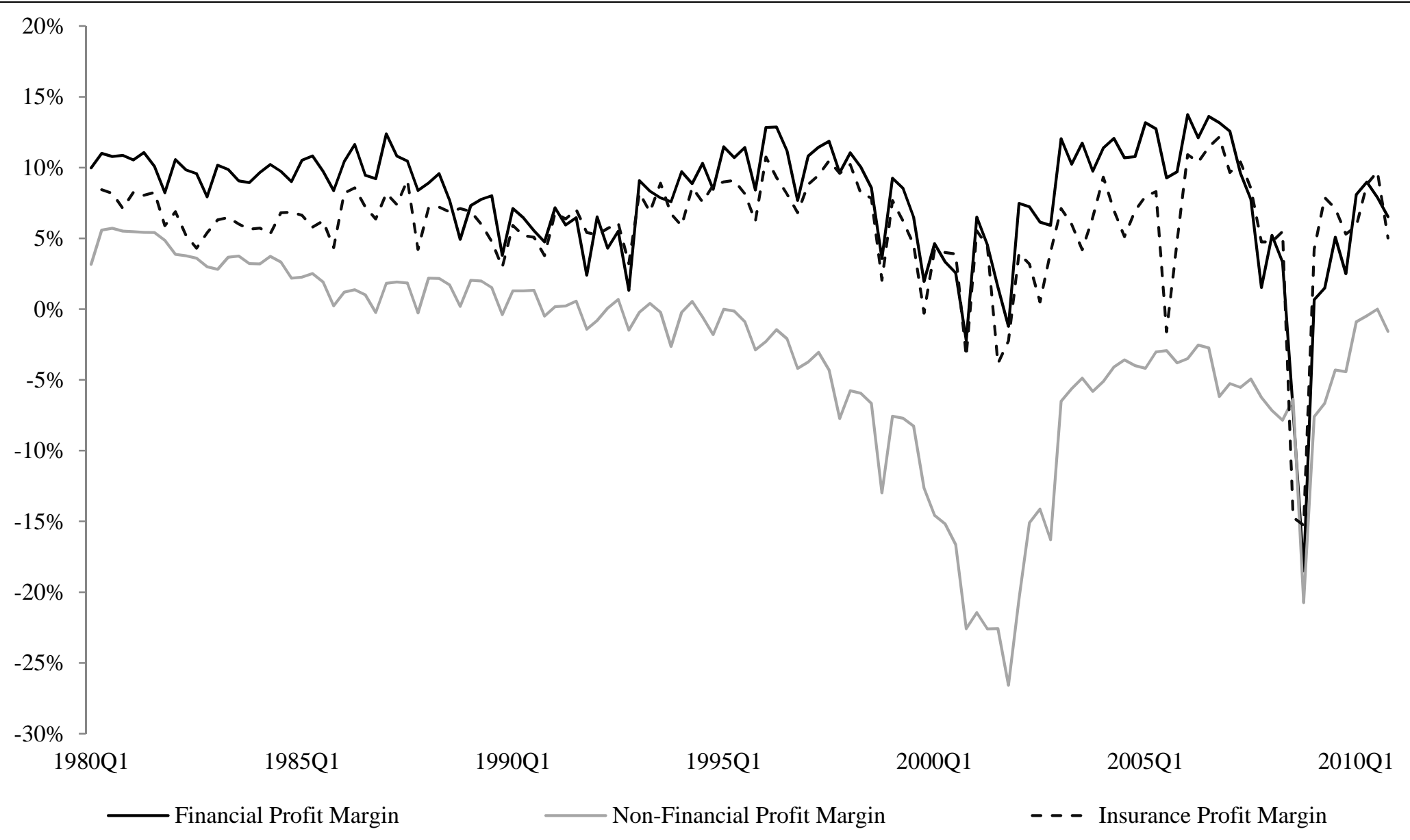


For the stock returns analysis presented in Section 6, we utilize monthly stock returns data from the CRSP database over the same 1980 through 2010 period. Likewise, we collect monthly observations for the key macroeconomic variables (GDP growth, Fed Funds, etc.) and distress variables (recession dummy and Financial Condition Index). We match these monthly data to the firm-specific, COMPUSTAT data. We apply the same filtering procedure defined above to ensure the stock return data is free from the influence of outliers and data entry errors. The final sample for the stock returns analysis contains $1,631,313$ firm-month observations over 15,676 firms.

\section{THE DETERMINANTS OF PROFITABILITY}

In this section, we present the results pertaining to the determinants of firm profitability and focus on the differences between financial firms and non-financial firms in times of economic distress. A difference of means analysis is presented in Table 2. The table splits our firm-level sample into three groups: All financial firms, insurance companies, as defined by SIC code, and all non-financial firms. The recession mean is compared with the non-recession mean for key firm statistics for each sample. We compare the magnitude of the differences of financial firms and insurance companies with those of the non-financial firms for an indicator as to the sensitivity of the different types of firms to a macroeconomic recession.

Panel A compares the differences in recession means for all financial firms with those of all nonfinancial firms. We find two interesting results. First, there is again evidence that firm profitability measured by profit margin is typically higher for financial firms. During non-recession periods, financial firms have an average quarterly profit margin of $8.7 \%$, while the non-financial average is $-3.5 \%$. Not surprisingly, both financial and non-financial firms experience significant decreases in profitability as the result of a recession. Another key result, however, is that the magnitude of the difference is much larger for the sample of financial firms. During a recession, a typical firm experiences a 3.8 percentage point reduction in quarterly profit margin, while the typical financial firm sees a 6.7 percentage point decrease. We also show a significant increase in the debt ratio of all firms during a recession. For financial firms, the 
debt ratio tends to increase by roughly one percentage point. This result is not surprising, but is of particular concern for financial institutions, which often have regulatory capital structure requirements. As expected, other key financial ratios such as ROA, ROE, and market-to-book are all significantly lower during a recession for all firms. We would not necessarily expect raw financial variables such as total assets and net income to show significant deterioration during recessions in our sample. This is due to the time dimension of our sample.

Panel B shows the difference of recession means for the insurance companies in our sample, as defined by SIC code. We see similar results to Panel A in terms of profitability. Profitability measures such as profit margin, ROA, and ROE are all significantly lower in recessions. This result is not particularly interesting. However, a key result is the magnitude of the decrease, compared with other types of firms. The tests in Panel B show that the average insurance company sees a decrease in profit margin of 5.5 percentage points. This is higher than that of the sample of non-financial firms, which experience a decrease of 3.8 percentage points, but lower than that of the sample of all financial firms, which experience a decrease of 6.7 percentage points on average. The decrease in average ROE and ROA and the increase in leverage that can be associated with a recession is similar across both Panels A and B for all firm types. Again, the effects appear to be more pronounced for the financial firm samples. The profitability results, in particular, may be an indication that insurance companies are less sensitive to financial crises than other financial firms. We explore this aspect with more statistical accuracy later in this section. 
Table 2: Difference of means during recessions

The following are difference of means tests on the sample of COMPUSTAT firms, sampled quarterly from 1980Q1 through $2010 \mathrm{Q} 4$. The data includes all firms with revenues of more than $\$ 500 \mathrm{~K}$ and is windsorized in each tail at the one percentile. The sample also requires each firm to have at least 8 quarters of complete data. Recession means are compared with non-recession means.

Panel A: Financial and Non-Financial

Samples

\begin{tabular}{|c|c|c|c|c|c|c|c|c|}
\hline \multirow[b]{2}{*}{ Variable } & \multicolumn{4}{|c|}{ Non-Financial Firms } & \multicolumn{4}{|c|}{ Financial Firms (SIC 6000-6999) } \\
\hline & $\begin{array}{c}\text { Non- } \\
\text { Recession } \\
\text { Mean }\end{array}$ & $\begin{array}{c}\text { Recession } \\
\text { Mean }\end{array}$ & Difference & $\begin{array}{c}\text { P- } \\
\text { value }\end{array}$ & $\begin{array}{c}\text { Non- } \\
\text { Recession } \\
\text { Mean }\end{array}$ & $\begin{array}{c}\text { Recession } \\
\text { Mean }\end{array}$ & $\begin{array}{c}\text { Differenc } \\
\text { e }\end{array}$ & P-value \\
\hline & & & & $<.000$ & & & & \\
\hline \multirow[t]{2}{*}{ Total Assets } & 1996.3 & 2621.0 & 624.7 & 1 & 15130.5 & 21544.9 & 6414.4 & $<.0001$ \\
\hline & & & & $<.000$ & & & & \\
\hline \multirow[t]{2}{*}{ Revenue } & 408.6 & 521.5 & 112.9 & 1 & 462.9 & 588.2 & 125.3 & $<.0001$ \\
\hline & & & & 0.275 & & & & \\
\hline \multirow[t]{2}{*}{ Net Income } & 21.6 & 20.7 & -0.9 & 7 & 37.3 & 9.3 & -28.0 & $<.0001$ \\
\hline & & & & $<.000$ & & & & \\
\hline \multirow[t]{2}{*}{ Profit Margin } & -0.035 & -0.073 & -0.038 & 1 & 0.087 & 0.020 & -0.067 & $<.0001$ \\
\hline & & & & $<.000$ & & & & \\
\hline \multirow[t]{2}{*}{$R O A$} & 0.002 & -0.002 & -0.004 & 1 & 0.007 & 0.002 & -0.004 & $<.0001$ \\
\hline & & & & $<.000$ & & & & \\
\hline \multirow[t]{2}{*}{ ROE } & -0.002 & -0.013 & -0.011 & 1 & 0.015 & 0.003 & -0.013 & $<.0001$ \\
\hline & & & & $<.000$ & & & & \\
\hline \multirow[t]{2}{*}{ Debt Ratio } & 0.496 & 0.503 & 0.006 & 1 & 0.626 & 0.635 & 0.009 & 0.001 \\
\hline & & & & $<.000$ & & & & \\
\hline \multirow[t]{2}{*}{ Market Cap } & 1787.4 & 2018.3 & 230.9 & 1 & 2031.9 & 2195.9 & 164 & 0.1227 \\
\hline & & & & $<.000$ & & & & \\
\hline \multirow[t]{2}{*}{ Market-to-Book } & 1.64 & 1.36 & -0.28 & 1 & 1.33 & 1.18 & -0.15 & $<.0001$ \\
\hline & & & & $<.000$ & & & & \\
\hline \multirow[t]{2}{*}{ Capital Expenditures } & 79.5 & 128.1 & 48.6 & 1 & 60.0 & 78.6 & 18.6 & 0.0 \\
\hline & & & & $<.000$ & & & & \\
\hline \multirow[t]{2}{*}{ Retained Earnings } & 347.2 & 507.2 & 160.0 & 1 & 702.1 & 831.1 & 129.0 & 0.0 \\
\hline & & & & 0.000 & & & & \\
\hline Cash & 233.2 & 264.8 & 31.6 & 4 & 1178.2 & 1202.4 & 24.2 & 0.8 \\
\hline
\end{tabular}

Panel B: Insurance Companies

\begin{tabular}{lcccc}
\hline & \multicolumn{3}{c}{ Insurance Companies (SIC Code 6299-6500) } \\
\hline Variable & $\begin{array}{c}\text { Non-Recession } \\
\text { Mean }\end{array}$ & $\begin{array}{c}\text { Recession } \\
\text { Mean }\end{array}$ & $\begin{array}{c}\text { Differenc } \\
\text { e }\end{array}$ & $\begin{array}{c}\text { P- } \\
\text { value }\end{array}$ \\
\hline Total Assets & & & 10019.90 & \\
Revenue & 17591.3 & 27611.2 & 0 & $<.0001$ \\
Net Income & 764.9 & 1078.2 & 313.300 & $<.0001$ \\
Profit Margin & 51.5 & 19.0 & -32.509 & $<.0001$ \\
ROA & 0.067 & 0.012 & -0.055 & $<.0001$ \\
ROE & 0.007 & 0.004 & -0.003 & $<.0001$ \\
Debt Ratio & 0.022 & 0.009 & -0.013 & $<.0001$ \\
Market Cap & 0.700 & 0.712 & 0.012 & 0.004 \\
Market-to-Book & 2715.7 & 3068.7 & 353.000 & 0.088 \\
Capital Expenditures & 1.08 & 1.05 & -0.029 & 0.278 \\
Retained Earnings & 24.8 & 32.9 & 8.110 & 0.160 \\
Cash & 1122.1 & 1447.1 & 325.000 & $<.0001$ \\
\hline
\end{tabular}


We now turn to a multivariate framework and attempt to more precisely measure the determinants of firm profitability and the effect of financial distress across firm types. Table 3 presents the results for the baseline model in from Eq. (1) for all firms. Three alternative specifications are presented. The dependent variable in all specifications is profitability as defined by profit margin — total net income divided by total revenues. We use the previously defined set of firm-specific and macroeconomic factors throughout, but alternate the measures of macroeconomic distress. In specification (1), we include both the recession dummy variable and the $\mathrm{NFCl}$ as measures of financial distress, while the two are alternated in specifications (2) and (3).

The results in Table 3 are consistent with previous studies regarding the factors that influence firm profitability and stock performance. We find that the signs and significance of Inflation, Real GDP Growth, Fed Funds Rate, and Spread are inconsistent across specifications. These variables are highly correlated, and thus this result is likely due to multicollinearity amongst these variables. We are not concerned with this, however, because correctly specifying the impact of these variables is not the focus of this analysis. Debt Ratio exhibits a significantly negative impact on firm profitability, as expected. At the means, increasing the debt ratio of a firm by one percentage point has the effect of reducing quarterly profit margin by 0.9 percentage points. Firm size, measured by total assets, is insignificant across specifications. This result is expected, because our fixed-effects estimation allows for firm cross-sectional differences, including size, to be captured in the intercept. We find significantly positive coefficients for lagged profit margin, indicating that profit margin is persistent. The presence of the quarterly dummy variable also adds explanatory power to the model.

The most important results for the baseline model are the measured impact of the financial distress variables, Recession Dummy and Financial Condition. We find, consistent with Table 2, that recessions have a significant impact on the cross-section of firm profitability. The recession dummy is significant at the five percent level across specifications. For an average firm in our sample, a recession causes average quarterly firm profitability to decrease by approximately 4.3 percentage points. The Financial 
Condition variable, however, is insignificant across both specifications for the full sample of firms. This result is explored in more detail in the following sections. 
Table 3: Base model results for all firms

Panel-OLS estimates of the effect of a set of macroeconomic and firm-specific factors on firm profitability, as defined by net income divided by total revenue. The coefficients are measured using a firm-level, cross-sectional fixed-effects, and White, autocorrelation standard errors are used to compute $p$-values. $P$-values are reported below each coefficient. Firm-level data is acquired using COMPUSTAT and is sampled on a quarterly basis from $1980 \mathrm{Q} 1$ to $2010 \mathrm{Q} 4$. We require at least 8 quarters of observations. The data is windsorized for each year at $1 \%$ in each tail. Macroeconomic variables are collected from the Federal Reserve of St. Louis FRED database. Spread is defined as the difference between the FEDFUNDS rate and the ten-year constant maturity Treasury bond. Debt ratio is defined as total liabilities divided by total assets. Financial Condition is the National Financial Conditions Index, which, measures risk in the debt and equity markets. Higher values represent tighter than normal conditions.

\begin{tabular}{|c|c|c|c|}
\hline Variable & (1) & $(2)$ & (3) \\
\hline \multirow[t]{2}{*}{ Inflation } & 0.0206 & 0.0181 & 0.0207 \\
\hline & 0.004 & 0.008 & 0.001 \\
\hline \multirow[t]{2}{*}{ Real GDP Growth } & -0.002 & 0.0104 & -0.0023 \\
\hline & 0.726 & 0.010 & 0.714 \\
\hline \multirow[t]{2}{*}{ Fed Funds Rate } & 0.0029 & 0.0022 & 0.0029 \\
\hline & 0.003 & 0.034 & 0.001 \\
\hline \multirow[t]{2}{*}{ Spread } & 0.0056 & 0.0039 & 0.0056 \\
\hline & 0.028 & 0.132 & 0.024 \\
\hline \multirow[t]{2}{*}{ Recession Dummy } & -0.0425 & & -0.0426 \\
\hline & 0.018 & & 0.009 \\
\hline \multirow[t]{2}{*}{ Financial Condition } & -0.0002 & -0.0042 & \\
\hline & 0.972 & 0.378 & \\
\hline \multirow[t]{2}{*}{ Total Assets } & 0.0000 & 0.0000 & 0.0000 \\
\hline & 0.738 & 0.596 & 0.733 \\
\hline \multirow[t]{2}{*}{ Debt Ratio } & -0.0960 & -0.0972 & -0.0960 \\
\hline & 0.000 & 0.000 & 0.000 \\
\hline \multirow[t]{2}{*}{ Profit Margin-1 } & 0.0003 & 0.0003 & 0.0003 \\
\hline & 0.007 & 0.007 & 0.007 \\
\hline \multirow[t]{2}{*}{ Q2 Dummy } & 0.0039 & 0.0004 & 0.0039 \\
\hline & 0.612 & 0.962 & 0.612 \\
\hline \multirow[t]{2}{*}{ Q3 Dummy } & 0.0014 & -0.0001 & 0.0014 \\
\hline & 0.857 & 0.987 & 0.857 \\
\hline \multirow[t]{2}{*}{ Q4 Dummy } & -0.0211 & -0.0229 & -0.0210 \\
\hline & 0.022 & 0.015 & 0.018 \\
\hline $\operatorname{Adj.} R^{2}$ & 0.423 & 0.422 & 0.423 \\
\hline No. of Firms & 17,591 & 17,591 & 17,591 \\
\hline$N$ & 699,211 & 699,211 & 699,211 \\
\hline F-stat & 30.12 & 30.04 & 30.12 \\
\hline
\end{tabular}


The purpose of this paper is to highlight the impact of financial distress on financial firms.

Accordingly, we present the same three baseline model specifications, but split the full sample into three subsamples: all financial firms, all non-financial firms and all firms in the insurance industry. The financial firm sample consists of 77,227 firm-quarter observations over 2,037 firms, the non-financial sample consists of 621,984 observations over 15,554 firms, and the insurance industry sample consists of 22,466 firm-quarter observations over 533 firms. The results for this analysis are presented in Table 4. Due to the high proportion of non-financial firms in the sample, the results for the sample of nonfinancial firms are very similar to those presented in the baseline model of the full sample from Table 3 . The results for the three samples share some characteristics as well. For example, all samples yield significant and positive coefficients for lagged profit margin and negative, significant coefficients for the recession dummy and debt ratio. However, the results for the financial sector firms differ significantly in some interesting ways.

The impact of the financial distress variables is much more pronounced in the financial firm sample. For the sample of non-financial firms, the recession dummy is significant in all specifications at the five percent level, while Financial Condition is not significant in any specification. Profit Margin for financial firms, however, is influenced by both the recession dummy and the financial condition index, regardless of specification. These results hold for both the sample of all financial firms at the one percent level and the sample of insurance companies at the ten percent level. The results in Table 4 show that non-financial profit margins are reduced by an average 4.16 percentage points during a recession, while those of financial firms are reduced by 4.83 percentage points. This corresponds with the previous univariate results presented in previous tables. In the sample of insurance firms, profit margins are reduced by 4.2 percentage points during a recession. This indicates that insurance companies are less sensitive to recessions than the full sample of financial firms, which experience a decline in profit margin of 4.8 percentage points, and are not significantly more sensitive to recessions than non-financial firms, which experience a decrease of 4.16 percentage points. Additionally, the 
Financial Condition coefficient for the sample of financial firms is $\mathbf{- 0 . 0 2 1}$, while that of the insurance company sample is $\mathbf{- 0 . 0 1 3}$.

This indicates that an increase in financial stress results in a larger decline in profitability for the full sample of financial firms than for insurance companies. In summary, the results of Table 4 indicate that insurance companies are more sensitive to financial crises than non-financial firms, but are less sensitive than the average financial firm. We aim to strengthen the validity of these results in the upcoming analyses. 
Table 4: The impact of the baseline model on financial firms

\begin{tabular}{|c|c|c|c|c|c|c|c|c|c|}
\hline \multicolumn{4}{|c|}{$\begin{array}{l}\text { Panel-OLS estimates of the effect of a set of macroecon } \\
\text { total revenue. The coefficients are measured using a fir } \\
\text { used to compute p-values. P-values are reported below } \\
\text { quarterly basis from 1980Q1 to } 2010 \mathrm{Q} 4 \text {. We require at I } \\
\text { Macroeconomic variables are collected from the Federa } \\
\text { FEDFUNDS rate and the ten-year constant maturity Tre } \\
\text { Condition is the National Financial Conditions Index, wl } \\
\text { normal conditions. } \\
\text { Financial Firms (SIC 6000-6999) }\end{array}$} & \multicolumn{3}{|c|}{ Non-Financial Firms } & $\begin{array}{l}\text { ty, as def } \\
\text {, autocor } \\
\text { ng COMP } \\
\text { dsorized f } \\
\text { defined a } \\
\text { ies divide } \\
\text { ets. Highe }\end{array}$ & $\begin{array}{l}\text { et incom } \\
\text { standard } \\
\text { d is samp } \\
\text { ear at } 1 \% \\
\text { erence be } \\
\text { l assets. } F \\
\text { represent }\end{array}$ & $\begin{array}{l}\text { ded by } \\
\text { s are } \\
n \text { a } \\
\text { ch tail. } \\
n \text { the } \\
\text { cial } \\
\text { ter than }\end{array}$ \\
\hline \multirow[t]{2}{*}{ Inflation } & 0.0048 & 0.0121 & 0.0027 & 0.0226 & 0.0218 & 0.0201 & -0.0028 & 0.0016 & -0.0046 \\
\hline & 0.6460 & 0.3920 & 0.7990 & -0.0190 & 0.0000 & 0.0030 & 0.8200 & 0.9130 & 0.7160 \\
\hline \multirow[t]{2}{*}{ Real GDP Growth } & 0.0139 & 0.0124 & 0.0257 & -0.0042 & -0.0040 & 0.0085 & 0.0092 & 0.0082 & 0.0204 \\
\hline & 0.0390 & 0.1170 & 0.0000 & 0.5350 & 0.5450 & 0.0330 & 0.1830 & 0.2750 & 0.0050 \\
\hline Recession Dummy & 0.0000 & 0.0000 & & 0.0290 & 0.0220 & & 0.0030 & 0.0010 & \\
\hline \multirow[t]{2}{*}{ Total Assets } & 0.0000 & 0.0000 & 0.0000 & 0.0000 & 0.0000 & 0.0000 & 0.0000 & 0.0000 & 0.0000 \\
\hline & 0.8140 & 0.9960 & 0.8790 & 0.2430 & 0.2010 & 0.4330 & 0.3770 & 0.3130 & 0.3550 \\
\hline \multirow[t]{2}{*}{ Debt Ratio } & -0.3076 & -0.3080 & -0.3096 & -0.0723 & -0.0723 & -0.0733 & -0.2813 & -0.2816 & -0.2828 \\
\hline & 0.0000 & 0.0000 & 0.0000 & 0.0000 & 0.0000 & 0.0000 & 0.0000 & 0.0000 & 0.0000 \\
\hline \multirow[t]{2}{*}{ Profit Margin-1 } & 0.0003 & 0.0003 & 0.0003 & 0.0003 & 0.0003 & 0.0003 & 0.0315 & 0.0317 & 0.0316 \\
\hline & 0.0490 & 0.0480 & 0.0490 & 0.0120 & 0.0120 & 0.0120 & 0.0140 & 0.0130 & 0.0140 \\
\hline \multirow[t]{2}{*}{ Spread } & 0.0000 & 0.0009 & -0.0015 & 0.0064 & 0.0064 & 0.0047 & -0.0017 & -0.0011 & -0.0031 \\
\hline & 1.0000 & 0.7460 & 0.5850 & 0.0160 & 0.0140 & 0.0800 & 0.5150 & 0.6580 & 0.2410 \\
\hline \multirow[t]{2}{*}{ Financial Condition } & -0.0176 & & -0.0210 & 0.0020 & & -0.0020 & -0.0101 & & -0.0132 \\
\hline & 0.0010 & & 0.0000 & 0.7050 & & 0.6830 & 0.0950 & & 0.0290 \\
\hline Adj. $R^{2}$ & 0.2810 & 0.2800 & 0.2810 & 0.4310 & 0.4310 & 0.4300 & 0.2200 & 0.2190 & 0.2190 \\
\hline No. of Firms & 2,037 & 2,037 & 2,037 & 15,554 & 15,554 & 15,554 & 533 & 533 & 533 \\
\hline Obs. & 77,227 & 77,227 & 77,227 & 621,984 & 621,984 & 621,984 & 22,466 & 22,466 & 22,466 \\
\hline F-stat & 15.76 & 15.69 & 15.71 & 31.29 & 31.29 & 31.20 & 12.66 & 12.63 & 12.58 \\
\hline
\end{tabular}


In the previous analyses, we compare the determinants of firm profitability of financial and nonfinancial firms by comparing the results of regressions performed on separate samples. This allows for comparisons of the coefficient magnitudes across samples, but does not provide statistical tests of their differences. A more robust analysis is one that allows for a more direct comparison. Accordingly, we present a nested model whereby we test the impact of the financial distress measures on financial companies with the use of several dummy variables and interaction terms. By providing a regression framework that tests the entire sample, we achieve a set of results that statistically tests the differences in the impact of financial stress on different types of firms.

To this end, we create three sets of dummy variables. The first is a dummy variable that indicates whether the firm is a financial firm, defined by SIC code. The second is a dummy variable that indicates whether the firm is an insurance company, defined by SIC code. The third is a set of decade dummy variables. We then create a set of interaction terms between the financial distress variables, the financial/insurance dummies, and the decade dummies. This allows us to see the direct impact of financial distress variables on financial companies over time. Table 6 presents the results for several specifications. Specifications (1) - (3) show the impact of financial distress on financial firms by utilizing the financial dummy and distress variable interaction terms, while specifications (4) - (5) show the impact over time by incorporating the decade interaction terms.

The results coincide with previous results that suggest financial firms are more affected by financial distress. The significant negative coefficient on Financial*Recession implies that financial firms experience a greater decrease in profit margins than non-financial firms during a recession. The results from specification (2) imply that a recession will cause the profit margin of a financial firm to fall by approximately 3.5 percentage points more than a non-financial firm. An analogous argument holds for specification (3), where the Financial ${ }^{*}$ Condition interaction term is also negative and significant. The results are different for insurance companies, however. The Insurance*Recession and Insurance* Condition variables show the impact of recessions and financial stress, respectively, on insurance firm profitability. We find that these variables report positive coefficients of approximately 
0.01. However, it is important to note that the Insurance* Recession is insignificant as the highest pvalue is 0.144 . The Insurance ${ }^{*}$ Condition variable is also only significant at the 10 percent level. Thus, the nested model shows that insurance companies do not appear to be any more sensitive to recessions than the average sample firm (including both financial and non-financial). The positive coefficient of Insurance* Condition indicates that insurance companies may be better able to handle financial stress when there is no recession. Other results also hold from the previous analyses. For example, the coefficient of Debt Ratio remains significant and negative, and the coefficient of lagged profit margin remains significant and positive. The magnitude of the effect of the Recession Dummy and Financial ConditionsIndex on all firms also remains similar.

Another aspect of the model presented in this section is the incorporation of the decade interaction terms included in the model. We find evidence supporting the idea that financial firms are disproportionately affected by key financial distress variables. It is therefore useful to understand how the magnitude of this effect has changed over time, especially in light of changes in the regulatory regime that have taken place over our sample period. Tables 5 and 6 shed some light on this topic.

In Table 5, we break down the financial and non-financial samples from Table 4 into decade subsamples. We then re-estimate the coefficients across decades for financial and non-financial firms. The results provide some evidence that the pronounced effect of financial distress on financial firms is driven by a greater sensitivity over years since 2000. The magnitude of the sensitivity of financial firm profitability to recessions increased from -.00182 during the 1980 s to -.039 in the 2000 s. This was accompanied by an increase in the significance as well. We also report a similar trend for Financial Condition. Its absolute magnitude and significance increase across the sample period. 
Table 5: The impact of the baseline model across decades

\begin{tabular}{|c|c|c|c|c|c|c|c|c|c|c|c|c|}
\hline \multicolumn{13}{|c|}{$\begin{array}{l}\text { Panel-OLS estimates of the effect of a set of macroeconomic and firm-specific factors on firm profitability, as defined by net in } \\
\text { sectional fixed-effects, and White, autocorrelation standard errors are used to compute p-values. P-values are reported belo } \\
\text { quarterly basis from } 1980 Q 1 \text { to } 2010 Q 4 \text {. We require at least } 8 \text { quarters of observations. The data is windsorized for each year a } \\
\text { Louis FRED database. Spread is defined as the difference between the FEDFUNDS rate and the ten-year constant maturity } T \\
\text { Condition is the National Financial Conditions Index, which, measures risk in the debt and equity markets. Higher values repre }\end{array}$} \\
\hline \multirow{2}{*}{ 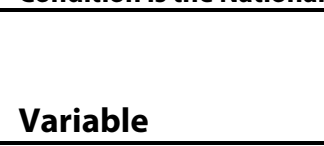 } & \multicolumn{6}{|c|}{ Non-Financial Firms } & \multicolumn{6}{|c|}{ Financial Firms } \\
\hline & $(1)$ & $(2)$ & $(1)$ & (2) & $(1)$ & (2) & $(1)$ & (2) & (1) & (2) & $(1)$ & $(2)$ \\
\hline \multirow[t]{2}{*}{ Inflation } & 0.0039 & 0.0041 & 0.0117 & 0.0046 & 0.0237 & 0.0244 & -0.0036 & -0.0033 & -0.0114 & -0.0149 & 0.0114 & 0.0028 \\
\hline & 0.030 & 0.019 & 0.008 & 0.399 & 0.004 & 0.004 & 0.540 & 0.588 & 0.204 & 0.073 & 0.408 & 0.791 \\
\hline Real GDP Growth & 0.0003 & -0.0001 & -0.0073 & 0.0006 & 0.0141 & 0.0373 & -0.0014 & -0.0020 & -0.0046 & -0.0009 & 0.0341 & 0.0343 \\
\hline \multirow[t]{2}{*}{ Fed Funds Rate } & 0.0034 & 0.0038 & 0.0072 & 0.0056 & -0.0526 & -0.0525 & 0.0042 & 0.0046 & 0.0029 & 0.0021 & -0.0034 & -0.0057 \\
\hline & 0.000 & 0.000 & 0.000 & 0.001 & 0.000 & 0.000 & 0.005 & 0.001 & 0.398 & 0.541 & 0.637 & 0.308 \\
\hline \multirow[t]{2}{*}{ Recession Dummy } & 0.0013 & & -0.0154 & & -0.0619 & & 0.0018 & & -0.0111 & & -0.0546 & \\
\hline & 0.834 & & 0.012 & & 0.000 & & 0.814 & & 0.233 & & 0.000 & \\
\hline \multirow[t]{2}{*}{ Financial Condition } & & -0.0027 & & -0.0113 & & 0.0016 & & -0.0025 & & -0.0039 & & -0.0388 \\
\hline & & 0.039 & & 0.028 & & 0.854 & & 0.300 & & 0.604 & & 0.000 \\
\hline \multirow[t]{2}{*}{ Total Assets } & 0.0000 & 0.0000 & 0.0000 & 0.0000 & 0.0000 & 0.0000 & 0.0000 & 0.0000 & 0.0000 & 0.0000 & 0.0000 & 0.0000 \\
\hline & 0.000 & 0.000 & 0.269 & 0.137 & 0.000 & 0.000 & 0.000 & 0.000 & 0.302 & 0.264 & 0.010 & 0.036 \\
\hline Debt Ratio & -0.1584 & -0.1580 & -0.1424 & -0.1420 & 0.0838 & 0.0819 & -0.3568 & -0.3568 & -0.2907 & -0.2906 & -0.2921 & -0.2869 \\
\hline Profit Margin $_{-1}$ & 0.003 & 0.003 & 0.182 & 0.183 & 0.045 & 0.044 & 0.057 & 0.057 & 0.008 & 0.008 & 0.203 & 0.207 \\
\hline \multirow[t]{2}{*}{ Spread } & 0.0032 & 0.0037 & 0.0095 & 0.0058 & -0.0644 & -0.0657 & 0.0083 & 0.0090 & -0.0040 & -0.0052 & -0.0092 & -0.0169 \\
\hline & 0.000 & 0.000 & 0.000 & 0.025 & 0.000 & 0.000 & 0.000 & 0.000 & 0.261 & 0.233 & 0.315 & 0.041 \\
\hline \multirow[t]{2}{*}{ Q2 Dummy } & 0.0015 & 0.0022 & 0.0043 & 0.0042 & 0.0152 & 0.0005 & -0.0018 & -0.0011 & -0.0090 & -0.0085 & -0.0148 & -0.0190 \\
\hline & 0.436 & 0.308 & 0.168 & 0.250 & 0.252 & 0.978 & 0.800 & 0.877 & 0.052 & 0.049 & 0.131 & 0.073 \\
\hline \multirow[t]{2}{*}{ Q3 Dummy } & -0.0009 & 0.0001 & 0.0031 & 0.0031 & 0.0042 & 0.0013 & -0.0105 & -0.0097 & -0.0137 & -0.0138 & -0.0296 & -0.0295 \\
\hline & 0.679 & 0.960 & 0.319 & 0.305 & 0.769 & 0.931 & 0.127 & 0.167 & 0.003 & 0.004 & 0.008 & 0.009 \\
\hline \multirow[t]{2}{*}{ Q4 Dummy } & -0.0126 & -0.0116 & -0.0236 & -0.0217 & -0.0313 & -0.0329 & -0.0229 & -0.0219 & -0.0427 & -0.0423 & -0.0520 & -0.0506 \\
\hline & 0.000 & 0.001 & 0.000 & 0.000 & 0.052 & 0.044 & 0.008 & 0.013 & 0.000 & 0.000 & 0.001 & 0.000 \\
\hline Adj. $R^{2}$ & 0.371 & 0.371 & 0.529 & 0.529 & 0.473 & 0.472 & 0.522 & 0.522 & 0.423 & 0.423 & 0.279 & 0.280 \\
\hline No. of Firms & 7,189 & 7,189 & 10,969 & 10,969 & 9,609 & 9,609 & 776 & 776 & 1,420 & 1,420 & 1,320 & 1,320 \\
\hline Obs. & 158,296 & 158,296 & 229,774 & 229,774 & 233,914 & 233,914 & 14,812 & 14,812 & 29,397 & 29,397 & 33,018 & 33,018 \\
\hline F-stat & 13.97 & 13.98 & 24.53 & 24.53 & 22.87 & 0.47 & 21.61 & 21.62 & 16.07 & 16.07 & 10.60 & 10.66 \\
\hline
\end{tabular}


Table 6 also sheds some light on this question in specifications (4) - (5). We include in specifications (4) - (5) several interaction terms that account for the marginal impact of financial distress variables on financial firms for each decade. Financial ${ }^{*}$ Recession*1990s and Financial*Recession*2000s are both negative and significant at the one percent level. We interpret this result as a recession that caused the profit margin to decrease about 2.6 percentage points more in the $1990 \mathrm{~s}$ than in the $1980 \mathrm{~s}$. This affect increased to approximately a 3.9 percentage point reduction in the 2000 s. We show an analogous result for Financial*Condition*2000s, which is also negative and significant at the one percent level. This result coincides with the previous evidence that financial firms' profitability sensitivity to financial market conditions has increased since the 1980s.

This evidence is contrasted by the results for the insurance company interaction terms. Specifications (4) and (5) show that the insurance dummy decade variables do not exhibit a consistent pattern with regards to each financial distress variable. The results show that insurance companies have actually improved performance when faced with a recession across the last two decades. This pattern does not hold for the Financial Condition variable, however. These results are not surprising, given the fact that we show the impact of the Financial Conditions Index and the Recession Dummy have both a statistically and economically smaller impact on insurance firm profitability than that of the average financial firm. 
Table 6: Nested model with financial sector and decade interaction terms

Panel-OLS estimates of the effect of a set of macroeconomic and firm-specific factors on firm profitability, as defined by net income divided by total revenue. The coefficients are measured using a firm-level, cross-sectional fixed-effects, and White, autocorrelation standard errors are used to compute p-values. P-values are reported below each coefficient. Firm-level data is acquired using COMPUSTAT and is sampled on a quarterly basis from 1980Q1 to 2010Q4. We require at least 8 quarters of observations. The data is windsorized for each year at $1 \%$ in each tail. Macroeconomic variables are collected from the Federal Reserve of St. Louis FRED database. Spread is defined as the difference between the FEDFUNDS rate and the ten-year constant maturity Treasury bond. Debt ratio is defined as total liabilities divided by total assets. Financial Condition is the National Financial Conditions Index, which, measures risk in the debt and equity markets. Higher values represent tighter than normal conditions.

\begin{tabular}{|c|c|c|c|c|c|}
\hline Variable & (1) & (2) & (3) & (4) & (5) \\
\hline \multirow[t]{2}{*}{ Inflation } & 0.0205 & 0.0206 & 0.0180 & 0.0166 & 0.0165 \\
\hline & 0.000 & 0.000 & 0.000 & 0.003 & 0.000 \\
\hline \multirow[t]{2}{*}{ Real GDP Growth } & -0.0023 & -0.0022 & 0.0104 & 0.0013 & 0.0114 \\
\hline & 0.005 & 0.004 & 0.000 & 0.812 & 0.000 \\
\hline \multirow[t]{2}{*}{ Fed Funds Rate } & 0.0028 & 0.0028 & 0.0022 & 0.0004 & 0.0015 \\
\hline & 0.000 & 0.000 & 0.000 & 0.671 & 0.000 \\
\hline \multirow[t]{2}{*}{ Recession Dummy } & -0.0398 & -0.0393 & & 0.0119 & \\
\hline & 0.000 & 0.000 & & 0.000 & \\
\hline \multirow[t]{2}{*}{ Financial Condition } & 0.0011 & & -0.0027 & & 0.0039 \\
\hline & 0.309 & & 0.006 & & 0.000 \\
\hline \multirow[t]{2}{*}{ Total Assets } & 0.0000 & 0.0000 & 0.0000 & 0.0000 & 0.0000 \\
\hline & 0.710 & 0.631 & 0.401 & 0.858 & 0.235 \\
\hline \multirow[t]{2}{*}{ Debt Ratio } & -0.0958 & -0.0958 & -0.0971 & -0.0957 & -0.0972 \\
\hline & 0.000 & 0.000 & 0.000 & 0.000 & 0.000 \\
\hline \multirow[t]{2}{*}{ Profit Margin-1 } & 0.0002 & 0.0003 & 0.0003 & 0.0003 & 0.0003 \\
\hline & 0.025 & 0.013 & 0.025 & 0.007 & 0.012 \\
\hline \multirow[t]{2}{*}{ Spread } & 0.0056 & 0.0056 & 0.0038 & 0.0035 & 0.0023 \\
\hline & 0.000 & 0.025 & 0.000 & 0.148 & 0.000 \\
\hline \multirow[t]{2}{*}{ Financial*Recession } & -0.0277 & -0.0345 & & & \\
\hline & 0.000 & 0.000 & & & \\
\hline \multirow[t]{2}{*}{ Financial*Condition } & -0.0141 & & -0.0168 & & \\
\hline & 0.000 & & 0.000 & & \\
\hline \multirow[t]{2}{*}{ Insurance*Recession } & 0.0102 & 0.0151 & & & \\
\hline & 0.290 & 0.144 & & & \\
\hline \multirow[t]{2}{*}{ Insurance* Condition } & 0.0095 & & 0.0110 & & \\
\hline & 0.086 & & 0.056 & & \\
\hline \multirow[t]{2}{*}{ Financial Condition*1990s } & & & & & -0.0171 \\
\hline & & & & & 0.000 \\
\hline \multirow[t]{2}{*}{ Financial Condition $* 2000$ s } & & & & & -0.0049 \\
\hline & & & & & 0.001 \\
\hline \multirow[t]{2}{*}{ Financial*Condition*1990s } & & & & & 0.0287 \\
\hline & & & & & 0.000 \\
\hline Financial ${ }^{*}$ Condition $* 2000$ s & & & & & -0.0518 \\
\hline & & & & & 0.000 \\
\hline Recession*1990s & & & & -0.0144 & \\
\hline & & & & 0.000 & \\
\hline Recession*2000s & & & & -0.0750 & \\
\hline & & & & 0.000 & \\
\hline Financial*Recession*1990s & & & & -0.0259 & \\
\hline & & & & 0.004 & \\
\hline Financial*Recession*2000s & & & & -0.0391 & \\
\hline & & & & 0.001 & \\
\hline Insurance ${ }^{*}$ Condition ${ }^{*} 1990$ s & & & & & -0.0164 \\
\hline & & & & & 0.075 \\
\hline Insurance ${ }^{*}$ Condition $* 2000 s$ & & & & & 0.0379 \\
\hline & & & & & 0.000 \\
\hline Insurance ${ }^{*}$ Recession*1990s & & & & 0.0184 & \\
\hline & & & & 0.087 & \\
\hline Insurance ${ }^{*}$ Recession $* 2000$ s & & & & 0.0251 & \\
\hline & & & & 0.092 & \\
\hline Q2 Dummy & 0.0039 & 0.0039 & 0.0004 & 0.0050 & -0.0000 \\
\hline & 0.000 & 0.000 & 0.657 & 0.513 & 0.994 \\
\hline Q3 Dummy & 0.0014 & 0.0014 & -0.0002 & 0.0010 & -0.0004 \\
\hline & 0.162 & 0.165 & 0.883 & 0.896 & 0.666 \\
\hline Q4 Dummy & -0.0211 & -0.0211 & -0.0230 & -0.0232 & -0.0230 \\
\hline & 0.000 & 0.000 & 0.000 & 0.007 & 0.000 \\
\hline $\operatorname{Adj} . R^{2}$ & 0.423 & 0.423 & 0.422 & 0.424 & 0.423 \\
\hline No. of Firms & 17,591 & 17,591 & 17,591 & 17,591 & 17,591 \\
\hline Obs. & 699,211 & 699,211 & 699,211 & 699,211 & 699,211 \\
\hline F-stat & 30.13 & 30.13 & 30.04 & 30.21 & 30.07 \\
\hline
\end{tabular}




\section{STOCK RETURN EFFECT}

In this section, we utilize the panel data regression framework to analyze the impact of financial distress on the cross-section of stock returns. We begin by establishing the baseline model used in Section $\mathbf{5}$ in the context of stock returns. The dependent variable for this framework is the total monthly stock return. The independent variables remain the same set of firm-specific and macroeconomic variables used in Section 5 , but lagged profit margin is replaced by the lagged monthly return and real GDP growth is replaced by the CRSP equal weighted market return. ${ }^{7}$ Results of the baseline model estimation are presented in Table 7.

The baseline stock return analysis shows results consistent with our previous finding that changes in the selected financial distress variables significantly affect the cross section of stock returns. The Financial Conditions Index has the expected negative sign and is significant in all specifications at the one percent level. The recession dummy variable is also negative and significant at the one percent level in specification (3). While the coefficients on Recession Dummy and Financial Condition are statistically significant in Table 7, their economic significance is quite small. A recession is associated with a -0.0005 percentage point reduction in monthly stock return for the average firm in the sample. This is quite small compared with the 4.3 percentage point reduction in profit margin associated with a recession found in Table 3. This result is not entirely unexpected, however. It is likely that investors are able to anticipate true firm fundamentals and they also have horizons beyond the current quarterly report. This would cause the impact of the distress variables to be diluted significantly.

\footnotetext{
${ }^{7}$ Our justification for replacing real GDP with the market return is a diversification argument. When investors hold diversified portfolios, they should only be willing to pay a premium associated with an asset's overall market risk exposure. The aim of our study is to show whether financial firms are sensitive to increased exposure to financial stress that may not be captured in the market index. Additionally, when including GDP in the regressions, the coefficients are either not statistically significant or economically small in impact.
} 
Table 7: The Baseline Model Results

Panel-OLS estimates of the effect of a set of macroeconomic and firm-specific factors on firm stock return. The coefficients are measured using firm-level, cross-sectional fixed-effects, and White autocorrelation-adjusted standard errors are used to compute p-values. P-values are reported below each coefficient. Firm-level financial data is acquired using COMPUSTAT and is sampled on a quarterly basis from 1980Q1 to 2010Q4. Stock return data is acquired through the CRSP database and is sampled on a monthly basis. We require at least 8 quarters of observations. The data is windsorized for each year at $1 \%$ in each tail. Macroeconomic variables are collected from the Federal Reserve of St. Louis FRED database and are sampled monthly. Market is defined as the CRSP equalweighted market index (EWRETD). Spread is defined as the difference between the FEDFUNDS rate and the ten-year constant maturity Treasury bond. Debt ratio is defined as total liabilities divided by total assets. Financial Condition is the National Financial Conditions Index, which, measures risk in the debt and equity markets. Higher values represent tighter than normal conditions.

\begin{tabular}{|c|c|c|c|}
\hline & $(1)$ & $(2)$ & (3) \\
\hline \multirow[t]{2}{*}{ Return $_{t-1}$} & -0.0408 & -0.0408 & -0.0406 \\
\hline & 0.000 & 0.000 & 0.000 \\
\hline \multirow[t]{2}{*}{ Inflation } & -0.0018 & -0.0018 & -0.0014 \\
\hline & 0.000 & 0.000 & 0.003 \\
\hline \multirow[t]{2}{*}{ Fed Funds Rate } & 0.0009 & 0.0009 & 0.0008 \\
\hline & 0.000 & 0.000 & 0.000 \\
\hline \multirow[t]{2}{*}{ Spread } & 0.0009 & 0.0009 & 0.0010 \\
\hline & 0.000 & 0.000 & 0.000 \\
\hline \multirow[t]{2}{*}{ Market Return } & 0.9276 & 0.9271 & 0.9288 \\
\hline & 0.000 & 0.000 & 0.000 \\
\hline \multirow[t]{2}{*}{ Recession Dummy } & -0.0005 & & -0.0009 \\
\hline & 0.179 & & 0.005 \\
\hline \multirow[t]{2}{*}{ Financial Condition } & -0.0013 & -0.0013 & \\
\hline & 0.000 & 0.000 & \\
\hline \multirow[t]{2}{*}{ Total Assets } & 0.0000 & 0.0000 & 0.00000 \\
\hline & 0.000 & 0.000 & 0.000 \\
\hline \multirow[t]{2}{*}{ Debt Ratio } & -0.0013 & -0.0013 & -0.0013 \\
\hline & 0.233 & 0.220 & 0.223 \\
\hline \multirow[t]{2}{*}{ Q2 Dummy } & 0.0049 & 0.0049 & 0.0048 \\
\hline & 0.000 & 0.000 & 0.000 \\
\hline \multirow[t]{2}{*}{ Q3 Dummy } & 0.0034 & 0.0034 & 0.0032 \\
\hline & 0.000 & 0.000 & 0.000 \\
\hline \multirow[t]{2}{*}{ Q4 Dummy } & 0.0061 & 0.0062 & 0.0059 \\
\hline & 0.000 & 0.000 & 0.000 \\
\hline Adj. $R^{2}$ & 0.139 & 0.139 & 0.139 \\
\hline No. of Firms & 15,676 & 15,676 & 15,676 \\
\hline$N$ & $1,631,383$ & $1,631,383$ & $1,631,383$ \\
\hline F-stat & 17.79 & 17.79 & 17.78 \\
\hline
\end{tabular}


To compare the effect of financial distress on the stock returns of financial and non-financial firms, we again divide the sample into financial, non-financial and insurance firm samples based on SIC code. We run the baseline specifications from Table 7 on the financial and non-financial samples and present the results in Table 8.

The results show that the larger magnitude of the impact of the distress variables on financial firms' profitability is echoed in the cross-section of stock returns. The Financial Conditions Index is negative and significant at the one percent level in all specifications, across all samples, and the recession dummy variable is negative and significant in specification (2) for the non-financial and financial sample at the five percent level. However, the recession dummy is not significant for either specification for the insurance sample. This is consistent with previous results that insurance firms are less sensitive to recessions. A recession is associated with a $\mathbf{- 0 . 0 0 2}$ percent monthly return for financial stocks, but there is only a -.0008 percent return for non-financial stocks. Also consistent with previous findings, the magnitude, or economic significance, of the effects of financial distress is much lower in the cross section of stock returns when compared to firm profitability. 
Table 8: The impact of the baseline model on financial firms

Panel-OLS estimates of the effect of a set of macroeconomic and firm-specific factors on firm stock return. The coefficients are measured using firm-level, cross-sectional fixed-effects, and White autocorrelation-adjusted standard errors are used to compute p-values. P-values are reported below each coefficient. Firm-level financial data is acquired using COMPUSTAT and is sampled on a quarterly basis from 1980Q1 to 2010Q4. Stock return data is acquired through the CRSP database and is sampled on a monthly basis. We require at least 8 quarters of observations. The data is windsorized for each year at $1 \%$ in each tail. Macroeconomic variables are collected from the Federal Reserve of St. Louis FRED database and are sampled monthly. Market is defined as the CRSP equal-weighted market index (EWRETD). Spread is defined as the difference between the FEDFUNDS rate and the ten-year constant maturity Treasury bond. Debt ratio is defined as total liabilities divided by total assets. Financial Condition is the National Financial Conditions Index, which, measures risk in the debt and equity markets. Higher values represent tighter than normal conditions.

\begin{tabular}{|c|c|c|c|c|c|c|c|c|c|}
\hline \multirow[b]{2}{*}{ Variable } & \multicolumn{3}{|c|}{ Financial Firms (SIC 6000-6999) } & \multicolumn{3}{|c|}{ Non-Financial Firms } & \multicolumn{3}{|c|}{ Insurance Companies } \\
\hline & (1) & (2) & (3) & (1) & (2) & (3) & (1) & (2) & (3) \\
\hline \multirow[t]{2}{*}{ Return $_{t-1}$} & -0.0485 & -0.0466 & -0.0485 & -0.0405 & -0.0403 & -0.0404 & -0.0489 & -0.0465 & -0.0489 \\
\hline & 0.000 & 0.000 & 0.000 & 0.000 & 0.000 & 0.000 & 0.000 & 0.000 & 0.000 \\
\hline Market Return & 0.000 & 0.000 & 0.000 & 0.000 & 0.000 & 0.000 & 0.000 & 0.000 & 0.000 \\
\hline \multirow[t]{2}{*}{ Fed Funds Rate } & 0.0014 & 0.0009 & 0.0014 & 0.0008 & 0.0008 & 0.0008 & 0.0026 & 0.0021 & 0.0026 \\
\hline & 0.000 & 0.000 & 0.000 & 0.000 & 0.000 & 0.000 & 0.000 & 0.000 & 0.000 \\
\hline \multirow[t]{2}{*}{ Spread } & 0.0005 & 0.0008 & 0.0005 & 0.0009 & 0.0010 & 0.0009 & 0.0007 & 0.0010 & 0.0007 \\
\hline & 0.034 & 0.001 & 0.033 & 0.000 & 0.000 & 0.000 & 0.062 & 0.007 & 0.059 \\
\hline \multirow[t]{2}{*}{ Inflation } & -0.0100 & -0.0081 & -0.0100 & -0.0006 & -0.0004 & -0.0006 & -0.0213 & -0.0191 & -0.0213 \\
\hline & 0.000 & 0.000 & 0.000 & 0.198 & 0.426 & 0.201 & 0.000 & 0.000 & 0.000 \\
\hline \multirow[t]{2}{*}{ Recession Dummy } & 0.0002 & -0.0023 & & -0.0005 & -0.0008 & & 0.0006 & -0.0021 & \\
\hline & 0.830 & 0.013 & & 0.150 & 0.028 & & 0.659 & 0.125 & \\
\hline \multirow[t]{2}{*}{ Financial Condition } & -0.0058 & & -0.0058 & -0.0007 & & -0.0008 & -0.0065 & & -0.0064 \\
\hline & 0.000 & & 0.000 & 0.000 & & 0.000 & 0.000 & & 0.000 \\
\hline \multirow[t]{2}{*}{ Total Assets } & 0.0000 & 0.0000 & 0.0000 & 0.0000 & 0.0000 & 0.0000 & 0.0000 & 0.0000 & 0.0000 \\
\hline & 0.000 & 0.000 & 0.000 & 0.002 & 0.002 & 0.002 & 0.921 & 0.737 & 0.930 \\
\hline Debt Ratio & 0.509 & 0.496 & 0.516 & 0.343 & 0.337 & 0.326 & 0.675 & 0.675 & 0.683 \\
\hline \multirow[t]{2}{*}{ Q2 Dummy } & 0.0046 & 0.0043 & 0.0046 & 0.0049 & 0.0049 & 0.0049 & 0.0080 & 0.0076 & 0.0080 \\
\hline & 0.000 & 0.000 & 0.000 & 0.000 & 0.000 & 0.000 & 0.000 & 0.000 & 0.000 \\
\hline \multirow[t]{2}{*}{ Q3 Dummy } & 0.0058 & 0.0054 & 0.0058 & 0.0031 & 0.0031 & 0.0031 & 0.0086 & 0.0082 & 0.0086 \\
\hline & 0.000 & 0.000 & 0.000 & 0.000 & 0.000 & 0.000 & 0.000 & 0.000 & 0.000 \\
\hline \multirow[t]{2}{*}{ Q4 Dummy } & 0.0042 & 0.0029 & 0.0042 & 0.0064 & 0.0062 & 0.0064 & 0.0123 & 0.0109 & 0.0123 \\
\hline & 0.000 & 0.001 & 0.000 & 0.000 & 0.000 & 0.000 & 0.000 & 0.000 & 0.000 \\
\hline $\operatorname{Adj.} R^{2}$ & 0.122 & 0.121 & 0.122 & 0.141 & 0.141 & 0.141 & 0.102 & 0.100 & 0.102 \\
\hline No. of Firms & 1,772 & 1,772 & 1,772 & 13,917 & 13,917 & 13,917 & 517 & 517 & 517 \\
\hline$N$ & 174,738 & 174,738 & 174,738 & $1,456,645$ & $1,456,645$ & $1,456,645$ & 58,680 & 58,680 & 58,680 \\
\hline F-stat & 14.65 & 14.51 & 14.66 & 18.22 & 18.22 & 18.22 & 13.63 & 13.43 & 13.65 \\
\hline
\end{tabular}


For a more direct comparison of the effects of financial distress, we again apply the nested model with the financial dummy variable interaction terms. The results are presented in Table 9. We find that, while the Financial ${ }^{*}$ Recession and Insurance* Recession interaction terms are insignificant in explaining the stock returns, the Financial ${ }^{*}$ Condition and Insurance ${ }^{*}$ Condition interaction terms are significant at the one percent level. The impact of increased stress is more negative for all financial firms. However, the effect of Insurance* Condition on insurance firms is positive and significant, while the Financial*Recession is not significant. This result indicates that insurance companies are not as affected by financial stress as other types of financial firms. This supports the results of the previous section that financial firms are affected differently and some are affected more significantly by financial distress than others. 
Table 9: Nested model with financial sector interaction terms

Panel-OLS estimates of the effect of a set of macroeconomic and firm-specific factors on firm stock return. The coefficients are measured using firm-level, cross-sectional fixed-effects, and White autocorrelation-adjusted standard errors are used to compute p-values. P-values are reported below each coefficient. Firm-level financial data is acquired using COMPUSTAT and is sampled on a quarterly basis from 1980Q1 to 2010Q4. Stock return data is acquired through the CRSP database and is sampled on a monthly basis. We require at least 8 quarters of observations. The data is windsorized for each year at $1 \%$ in each tail. Macroeconomic variables are collected from the Federal Reserve of St. Louis FRED database and are sampled monthly. Market is defined as the CRSP equalweighted market index (EWRETD). Spread is defined as the difference between the FEDFUNDS rate and the ten-year constant maturity Treasury bond. Debt ratio is defined as total liabilities divided by total assets. Financial Condition is the National Financial Conditions Index, which, measures risk in the debt and equity markets. Higher values represent tighter than normal conditions.

\begin{tabular}{|c|c|c|c|}
\hline Variable & (1) & (2) & (3) \\
\hline \multirow[t]{2}{*}{ Return $_{t-1}$} & -0.0408 & -0.0406 & -0.0408 \\
\hline & 0.000 & 0.000 & 0.000 \\
\hline \multirow[t]{2}{*}{ Market Return } & 0.9271 & 0.9288 & 0.9271 \\
\hline & 0.000 & 0.000 & 0.000 \\
\hline \multirow[t]{2}{*}{ Fed Funds Rate } & 0.0009 & 0.0008 & 0.0009 \\
\hline & 0.000 & 0.000 & 0.000 \\
\hline \multirow[t]{2}{*}{ Spread } & 0.0009 & 0.0001 & 0.0009 \\
\hline & 0.000 & 0.000 & 0.000 \\
\hline \multirow[t]{2}{*}{ Inflation } & -0.0018 & -0.0014 & -0.0018 \\
\hline & 0.000 & 0.003 & 0.000 \\
\hline \multirow[t]{2}{*}{ Recession Dummy } & -0.0007 & -0.0011 & \\
\hline & 0.061 & 0.003 & \\
\hline \multirow[t]{2}{*}{ Financial Condition } & -0.0011 & & -0.0011 \\
\hline & 0.000 & & 0.000 \\
\hline \multirow[t]{2}{*}{ Total Assets } & 0.0000 & 0.0000 & 0.0000 \\
\hline & 0.000 & 0.000 & 0.000 \\
\hline \multirow[t]{2}{*}{ Debt Ratio } & -0.0013 & -0.0013 & -0.0013 \\
\hline & 0.232 & 0.222 & 0.224 \\
\hline \multirow[t]{2}{*}{ Financial*Recession } & 0.0021 & 0.0008 & \\
\hline & 0.092 & 0.520 & \\
\hline \multirow[t]{2}{*}{ Financial*Financial Condition } & -0.0027 & & -0.0025 \\
\hline & 0.000 & & 0.000 \\
\hline \multirow[t]{2}{*}{ Insurance*Recession } & 0.0007 & 0.0019 & \\
\hline & 0.718 & 0.281 & \\
\hline \multirow[t]{2}{*}{ Insurance*Financial Condition } & 0.0028 & & 0.0028 \\
\hline & 0.002 & & 0.001 \\
\hline \multirow[t]{2}{*}{ Q2 Dummy } & 0.0049 & 0.0048 & 0.0049 \\
\hline & 0.000 & 0.000 & 0.000 \\
\hline \multirow[t]{2}{*}{ Q3 Dummy } & 0.0034 & 0.0033 & 0.0034 \\
\hline & 0.000 & 0.000 & 0.000 \\
\hline \multirow[t]{2}{*}{ Q4 Dummy } & 0.0062 & 0.0059 & 0.0062 \\
\hline & 0.000 & 0.000 & 0.000 \\
\hline $\operatorname{Adj.} R^{2}$ & 0.139 & 0.139 & 0.139 \\
\hline No. of Firms & 15,676 & 15,676 & 15,676 \\
\hline Obs. & $1,631,383$ & $1,631,383$ & $1,631,383$ \\
\hline F-stat & 17.78 & 17.78 & 17.79 \\
\hline
\end{tabular}




\section{FURTHER ANALYSIS OF THE FINANCE INDUSTRY}

We show in previous sections that there is evidence supporting the idea that financial service companies are more affected by changes in key financial distress variables then their real sector counterparts. This has many important real sector productivity and policy implications. Therefore, comparing the impact of financial distress across sub-industries within the finance industry is an important part of identifying the potential sources and solutions to this problem. As a final analysis of the impact of financial distress on financial firms, we provide a more detailed analysis of the financial services industry. We begin by dividing the sample of financial firms into six sub-industries based on SIC code: depository institutions, finance companies, financial services, insurance, real estate, and investment companies. Table 10 presents the descriptive statistics for these subsamples of financial firms.

Depository institutions have the highest average total assets with an average of $\$ 63.2 \mathrm{~B}$, and they also have the highest average revenues and net income per quarter at \$1.1B and \$114.3M, respectively. For the average firm, profit margins are 5.3\% for depository institutions, $7.3 \%$ for finance companies, 4.1\% for financial services firms, $6.1 \%$ for insurance companies, $10 \%$ for real estate companies and $14.1 \%$

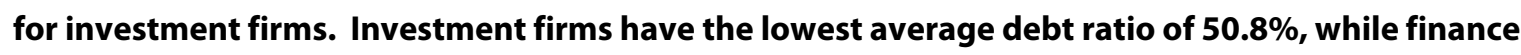
companies have the highest at $76.1 \%$. 
Table 10: Financial firm summary statistics

The following are descriptive statistics on a sample of COMPUSTAT Financial firms (SIC code 6000-6999), sampled quarterly from 1980Q1 through 2010Q4. The data includes all firms with revenues of more than $\$ 500 \mathrm{~K}$ and is windsorized in each tail at the one percentile. The sample also requires each firm to have at least 8 quarters of complete data.

\begin{tabular}{|c|c|c|c|c|c|c|c|c|c|c|c|}
\hline & & \multicolumn{4}{|c|}{ All Financial Firms } & \multicolumn{6}{|c|}{ SIC Industry } \\
\hline & & Full sample & $1980 s$ & $1990 \mathrm{~s}$ & $2000 s$ & Depository & Finance & Services & Insurance & Real Estate & Investment \\
\hline \multicolumn{12}{|c|}{ Total Assets } \\
\hline & Mean & 15941.9 & 3072.3 & 7684.9 & 29066.7 & 63161.7 & 27130.9 & 34298.0 & 18779.0 & 747.6 & 1449.9 \\
\hline & Std. Dev. & 92453.8 & 10805.4 & 32528.6 & 136715.6 & 126997.5 & 126314.7 & 155380.0 & 92860.2 & 3368.6 & 3460.5 \\
\hline \multicolumn{12}{|c|}{ Revenue } \\
\hline & Mean & 478.8 & 194.4 & 286.0 & 778.0 & 1104.5 & 709.3 & 676.3 & 802.1 & 52.7 & 68.4 \\
\hline & Std. Dev. & 1934.6 & 624.5 & 970.3 & 2753.5 & 1888.6 & 2592.3 & 2445.6 & 2447.0 & 193.2 & 275.3 \\
\hline \multicolumn{12}{|c|}{ Net Income } \\
\hline & Mean & 33.7 & 10.4 & 21.7 & 54.9 & 114.3 & 59.7 & 44.0 & 47.7 & 2.6 & 7.3 \\
\hline & Std. Dev. & 256.4 & 34.0 & 89.9 & 381.2 & 259.4 & 414.2 & 389.9 & 249.6 & 30.1 & 33.2 \\
\hline \multicolumn{12}{|c|}{ Profit Margin } \\
\hline & Mean & 0.078 & 0.092 & 0.084 & 0.067 & 0.053 & 0.073 & 0.041 & 0.061 & 0.010 & 0.141 \\
\hline & Std. Dev. & 0.344 & 0.216 & 0.290 & 0.425 & 0.259 & 0.365 & 0.311 & 0.234 & 0.332 & 0.429 \\
\hline \multicolumn{12}{|l|}{$R O A$} \\
\hline & Mean & 0.006 & 0.008 & 0.006 & 0.005 & 0.004 & 0.004 & 0.007 & 0.007 & 0.004 & 0.007 \\
\hline & Std. Dev. & 0.027 & 0.022 & 0.026 & 0.030 & 0.030 & 0.022 & 0.041 & 0.022 & 0.026 & 0.026 \\
\hline \multicolumn{12}{|l|}{ ROE } \\
\hline & Mean & 0.014 & 0.019 & 0.014 & 0.011 & 0.016 & 0.016 & 0.016 & 0.020 & 0.001 & 0.010 \\
\hline & Std. Dev. & 0.096 & 0.087 & 0.096 & 0.099 & 0.108 & 0.108 & 0.114 & 0.088 & 0.105 & 0.081 \\
\hline & Mean & 0.627 & 0.643 & 0.624 & 0.622 & 0.700 & 0.761 & 0.591 & 0.701 & 0.590 & 0.508 \\
\hline & Std. Dev. & 0.253 & 0.247 & 0.259 & 0.250 & 0.284 & 0.218 & 0.286 & 0.202 & 0.231 & 0.244 \\
\hline \multicolumn{12}{|c|}{ Market Cap } \\
\hline & Mean & 2052.9 & 391.8 & 1110.8 & 3491.3 & 6591.2 & 3511.0 & 3010.5 & 2757.5 & 313.0 & 741.2 \\
\hline & Std. Dev. & 9201.5 & 1044.9 & 4823.2 & 12837.3 & 13391.3 & 18366.1 & 10075.9 & 9633.7 & 1182.0 & 1640.0 \\
\hline \multicolumn{12}{|c|}{ Market-to-Book Ratio } \\
\hline & Mean & 1.29 & 0.95 & 1.00 & 1.29 & 1.41 & 1.04 & 1.77 & 1.07 & 1.15 & 1.33 \\
\hline & Std. Dev. & 1.06 & 0.01 & 0.01 & 1.06 & 0.86 & 0.35 & 1.64 & 0.44 & 0.50 & 1.24 \\
\hline \multicolumn{12}{|c|}{ Capital Expenditures } \\
\hline & Mean & 62.0 & 15.2 & 49.4 & 87.9 & 49.9 & 308.6 & 36.0 & 25.7 & 23.6 & 5.5 \\
\hline & Std. Dev. & 638.1 & 114.0 & 592.8 & 762.0 & 115.3 & 1603.5 & 148.4 & 253.6 & 180.4 & 50.3 \\
\hline \multicolumn{12}{|c|}{ Retained Earnings } \\
\hline & Mean & 718.6 & 211.3 & 396.2 & 1224.5 & 1865.6 & 1350.5 & 1046.1 & 1161.0 & 54.1 & -64.3 \\
\hline & Std. Dev. & 3882.9 & 575.7 & 1546.4 & 5676.2 & 3792.3 & 6956.6 & 4339.6 & 3891.4 & 391.5 & 251.2 \\
\hline \multicolumn{12}{|l|}{ Cash } \\
\hline & Mean & 1187.3 & 26.4 & & 1187.6 & 5472.6 & 2773.4 & 1986.1 & 1208.3 & 73.5 & 106.0 \\
\hline & Std. Dev. & 5748.5 & 30.9 & & 5749.1 & 16566.8 & 8658.6 & 7759.0 & 3805.8 & 215.2 & 318.0 \\
\hline
\end{tabular}


We continue the analysis of financial firms by applying the baseline firm profitability model presented in Section $\mathbf{5}$ to the subsample of financial firms. The model is applied to each financial subsample, and the results are reported in Table 11. The dependent variable is quarterly firm profit margin.

A major result of this analysis is that both the financial condition and recession dummyvariable coefficients are insignificant for depository institutions and for the real estate industry. This implies that the pronounced effects of these variables on financial firm profitability and stock returns may be driven by sectors of the financial industry outside of depository institutions and real estate. Conversely, for the remainder of the sectors, both variables are significant at the one percent level. Table 11 suggests that the most sensitive sector to financial distress is financial services. A recession is associated with a $6.8 \%$ drop in profit margin for financial services companies. The percentage point decrease in profit margin associated with a recession for finance companies, insurance companies, and investment companies are likewise 5.3\%, 4.2\%, and $5.0 \%$, respectively. The results suggest that the pronounced impact of financial distress on financial firms is likely driven by financial services, finance companies and investment firms. 


\begin{tabular}{|c|c|c|c|c|c|c|c|c|c|c|c|c|}
\hline \multicolumn{13}{|c|}{$\begin{array}{l}\text { Panel-OLS estimates of the effect of a set of macroeconomic and firm-specific factors on firm profitability, as defined by net } \\
\text { income divided by total revenue. The coefficients are measured using a firm-level, cross-sectional fixed-effects, and White, } \\
\text { autocorrelation standard errors are used to compute p-values. P-values are reported below each coefficient. Firm-level data is } \\
\text { acquired using COMPUSTAT and is sampled on a quarterly basis from } 1980 \mathrm{Q} 1 \text { to } 2010 \mathrm{Q} 4 \text {. We require at least } 8 \text { quarters of } \\
\text { observations. The data is windsorized for each year at } 1 \% \text { in each tail. Macroeconomic variables are collected from the Federal } \\
\text { Reserve of St. Louis FRED database. Spread is defined as the difference between the FEDUNDS rate and the ten-year constant } \\
\text { maturity Treasury bond. Debt ratio is defined as total liabilities divided by total assets. Financial Condition is the National } \\
\text { Financial Conditions Index, which, measures risk in the debt and equity markets. Higher values represent tighter than normal } \\
\text { conditions. }\end{array}$} \\
\hline \multirow[b]{2}{*}{ Variable } & \multicolumn{2}{|c|}{ Depository } & \multicolumn{2}{|c|}{ Finance } & \multicolumn{2}{|c|}{ Services } & \multicolumn{2}{|c|}{ Insurance } & \multicolumn{2}{|c|}{ Real Estate } & \multicolumn{2}{|c|}{ Investment } \\
\hline & (1) & (2) & (1) & (2) & (1) & (2) & (1) & (2) & (1) & (2) & (1) & (2) \\
\hline \multirow[t]{2}{*}{ Inflation } & 0.0208 & 0.0291 & 0.0202 & 0.0008 & 0.0171 & 0.0039 & 0.0016 & $\begin{array}{c}- \\
0.0046\end{array}$ & 0.0166 & 0.0143 & 0.0096 & 0.0012 \\
\hline & 0.330 & 0.117 & 0.059 & 0.933 & 0.020 & 0.590 & 0.763 & 0.361 & 0.118 & 0.153 & 0.220 & 0.881 \\
\hline Real GDP & - & - & & & & & & & & & & \\
\hline \multirow[t]{2}{*}{ Growth } & 0.0244 & 0.0214 & 0.0166 & 0.0306 & 0.0166 & 0.0355 & 0.0082 & 0.0204 & 0.0112 & 0.0177 & 0.0153 & 0.0290 \\
\hline & $\begin{array}{c}0.154 \\
-\end{array}$ & $\begin{array}{c}0.169 \\
-\end{array}$ & 0.036 & 0.000 & 0.015 & 0.000 & 0.026 & 0.000 & 0.098 & 0.006 & 0.005 & 0.000 \\
\hline \multirow[t]{2}{*}{ Fed Funds Rate } & 0.0189 & 0.0209 & 0.0044 & 0.0087 & 0.0023 & 0.0037 & 0.0023 & 0.0028 & 0.0045 & 0.0045 & 0.0073 & 0.0082 \\
\hline & 0.004 & 0.001 & 0.049 & 0.001 & 0.553 & 0.324 & 0.080 & 0.044 & 0.204 & 0.191 & 0.038 & 0.023 \\
\hline \multirow{3}{*}{$\begin{array}{l}\text { Recession } \\
\text { Dummy }\end{array}$} & & & - & & - & & - & & - & & - & \\
\hline & 0.0015 & & 0.0528 & & 0.0686 & & 0.0422 & & 0.0227 & & 0.0499 & \\
\hline & 0.947 & & 0.000 & & 0.000 & & 0.000 & & 0.172 & & 0.000 & \\
\hline \multirow[t]{2}{*}{$\begin{array}{l}\text { Financial } \\
\text { Condition }\end{array}$} & & 0.0197 & & 0.0483 & & $\begin{array}{c}- \\
0.0277\end{array}$ & & $\begin{array}{c}- \\
0.0132\end{array}$ & & $\begin{array}{c}- \\
0.0052\end{array}$ & & 0.0185 \\
\hline & & 0.242 & & 0.000 & & 0.000 & & 0.002 & & 0.473 & & 0.006 \\
\hline \multirow[t]{3}{*}{ Total Assets } & 0.0000 & 0.0000 & 0.0000 & 0.0000 & 0.0000 & 0.0000 & 0.0000 & 0.0000 & 0.0000 & 0.0000 & 0.0000 & 0.0000 \\
\hline & 0.727 & 0.391 & 0.504 & 0.221 & 0.252 & 0.308 & 0.180 & 0.251 & 0.726 & 0.707 & 0.909 & 0.795 \\
\hline & - & - & - & - & - & - & - & - & - & - & - & - \\
\hline \multirow[t]{2}{*}{ Debt Ratio } & 0.0831 & 0.0792 & 0.3606 & 0.3594 & 0.0553 & 0.0570 & 0.2816 & 0.2828 & 0.2511 & 0.2525 & 0.4169 & 0.4193 \\
\hline & 0.491 & 0.502 & 0.000 & 0.000 & 0.371 & 0.361 & 0.000 & 0.000 & 0.000 & 0.000 & 0.000 & 0.000 \\
\hline \multirow[t]{3}{*}{ Profit Margin-1 } & 0.0023 & 0.0023 & 0.0132 & 0.0128 & 0.0014 & 0.0014 & 0.0317 & 0.0316 & 0.0001 & 0.0001 & 0.0245 & 0.0246 \\
\hline & 0.000 & 0.000 & 0.297 & 0.302 & 0.711 & 0.706 & 0.015 & 0.015 & 0.000 & 0.000 & 0.000 & 0.000 \\
\hline & - & - & & & & & - & - & - & - & - & - \\
\hline \multirow[t]{4}{*}{ Spread } & 0.0079 & 0.0073 & 0.0086 & 0.0057 & 0.0051 & 0.0018 & 0.0011 & 0.0031 & 0.0052 & 0.0062 & 0.0012 & 0.0036 \\
\hline & 0.183 & 0.198 & 0.078 & 0.242 & 0.202 & 0.664 & 0.537 & 0.084 & 0.245 & 0.153 & 0.795 & 0.414 \\
\hline & & & - & - & - & - & - & - & - & - & - & - \\
\hline & 0.0055 & 0.0037 & 0.0192 & 0.0193 & 0.0119 & 0.0163 & 0.0046 & 0.0077 & 0.0055 & 0.0071 & 0.0191 & 0.0228 \\
\hline \multirow[t]{3}{*}{ Q2 Dummy } & 3 & 2 & 0 & 6 & 5 & 1 & 5 & 2 & 9 & 3 & 9 & 7 \\
\hline & 0.713 & 0.800 & 0.001 & 0.002 & 0.048 & 0.007 & 0.096 & 0.008 & 0.480 & 0.361 & 0.001 & 0.000 \\
\hline & & & - & - & - & - & - & - & - & - & - & - \\
\hline \multirow[t]{3}{*}{ Q3 Dummy } & 0.0121 & 0.0093 & 0.0297 & 0.0242 & 0.0162 & 0.0145 & 0.0216 & 0.0217 & 0.0157 & 0.0160 & 0.0220 & 0.0217 \\
\hline & 0.345 & 0.427 & 0.000 & 0.001 & 0.020 & 0.033 & 0.000 & 0.000 & 0.094 & 0.096 & 0.000 & 0.000 \\
\hline & - & - & - & - & - & - & - & - & - & - & - & - \\
\hline \multirow[t]{2}{*}{ Q4 Dummy } & 0.0200 & 0.0239 & 0.0527 & 0.0435 & 0.0249 & 0.0212 & 0.0328 & 0.0324 & 0.0506 & 0.0508 & 0.0601 & 0.0597 \\
\hline & 0.042 & 0.018 & 0.000 & 0.000 & 0.001 & 0.003 & 0.000 & 0.000 & 0.000 & 0.000 & 0.000 & 0.000 \\
\hline Adj. $R^{2}$ & 0.323 & 0.325 & 0.221 & 0.226 & 0.220 & 0.220 & 0.219 & 0.219 & 0.247 & 0.247 & 0.337 & 0.337 \\
\hline No. of Firms & 52 & 52 & 308 & 308 & 260 & 260 & 533 & 533 & 253 & 253 & 631 & 631 \\
\hline Obs. & 1,944 & 1,944 & 11,664 & 11,664 & 9,634 & 9,634 & 22,466 & 22,466 & 8,703 & 8,703 & 22,816 & 22,816 \\
\hline F-stat & 15.93 & 16.08 & 11.39 & 11.73 & 11.09 & 11.09 & 12.63 & 12.58 & 11.86 & 11.85 & 19.12 & 19.11 \\
\hline
\end{tabular}


Following our framework presented in the previous sections, we conclude our analysis of financial companies by directly comparing the determinants of financial sector profits across sub-sectors using a nested model framework. We begin by constructing several dummy variables that represent each subsector within the financial industry: Finance, Insurance, Investment, Real Estate, and Services. We then use the sub-sector dummies to create an interaction term with the financial distress variables. In this model, non-financial institutions are the baseline, and the interaction terms describe the marginal impact of the financial distress measures on the average firm in each financial sub-sector. The results of this analysis are presented in Table 12.

The conclusion that the financial sector results are driven by non-depository institutions is supported by the results reported in Table 12. All financial sub-sector interaction terms except for those of the depository institutions are negative and many are significant. This shows that the negative impact of the financial distress variables is driven by non-depository institutions. It also shows which non-depository institutions are impacted the most. For the non-depository financial institutions, a recession has the least effect on real estate companies, followed by insurance companies, finance companies, financial services, and investment firms. However, the recession interaction term is not significant for real estate or finance companies. Also, the financial conditions index interaction term is only significant for finance and financial services firms. A recession has the effect of lowering insurance firm profitability 1.9 percentage points more than the average firm in the sample of COMPUSTAT firms. This compares with a 4.6 percentage point decrease below the average for investment companies, a 5.2 percentage point decrease for financial services companies, and a 4.1 percentage point decrease for financial services companies. These results support the conclusion that although insurance company profitability is more sensitive to macroeconomic shocks than non-financial firms, the magnitude of this sensitivity is significantly lower than other types of financial institutions. 
Table 12: Nested model with financial type interaction terms

Panel-OLS estimates of the effect of a set of macroeconomic and firm-specific factors on firm profitability, as defined by net income divided by total revenue. The coefficients are measured using a firm-level, cross-sectional fixed-effects, and White, autocorrelation standard errors are used to compute $p$-values. P-values are reported below each coefficient. Firm-level data is acquired using COMPUSTAT and is sampled on a quarterly basis from 1980Q1 to 2010Q4. We require at least 8 quarters of observations. The data is windsorized for each year at $1 \%$ in each tail. Macroeconomic variables are collected from the Federal Reserve of St. Louis FRED database. Spread is defined as the difference between the FEDFUNDS rate and the ten-year constant maturity Treasury bond. Debt ratio is defined as total liabilities divided by total assets. Financial Condition is the National Financial Conditions Index, which, measures risk in the debt and equity markets. Higher values represent tighter than normal conditions.

\begin{tabular}{|c|c|c|c|}
\hline Variable & (1) & (2) & (3) \\
\hline \multirow{2}{*}{ Inflation } & 0.0205 & 0.0206 & 0.0181 \\
\hline & 0.000 & 0.000 & 0.000 \\
\hline \multirow[t]{2}{*}{ Real GDP Growth } & -0.0023 & -0.0022 & 0.0104 \\
\hline & 0.008 & 0.006 & 0.000 \\
\hline \multirow[t]{2}{*}{ Fed Funds Rate } & 0.0028 & 0.0028 & 0.0022 \\
\hline & 0.000 & 0.000 & 0.000 \\
\hline \multirow[t]{2}{*}{ Recession Dummy } & -0.0398 & -0.0393 & \\
\hline & 0.000 & 0.000 & \\
\hline \multirow[t]{2}{*}{ Financial Condition } & 0.0011 & & -0.0027 \\
\hline & 0.307 & & 0.006 \\
\hline \multirow[t]{2}{*}{ Total Assets } & 0.0000 & 0.0000 & 0.0000 \\
\hline & 0.501 & 0.615 & 0.311 \\
\hline \multirow[t]{2}{*}{ Debt Ratio } & -0.0956 & -0.0958 & -0.0970 \\
\hline & 0.000 & 0.000 & 0.000 \\
\hline \multirow[t]{2}{*}{ Profit Margin $_{-1}$} & 0.0003 & 0.0003 & 0.0003 \\
\hline & 0.025 & 0.025 & 0.025 \\
\hline \multirow[t]{2}{*}{ Spread } & 0.0056 & 0.0056 & 0.0038 \\
\hline & 0.000 & 0.000 & 0.000 \\
\hline \multirow[t]{2}{*}{ Deposit*Recession } & 0.0703 & 0.0752 & \\
\hline & 0.004 & 0.000 & \\
\hline \multirow[t]{2}{*}{ Deposit*Condition } & 0.0075 & & 0.0176 \\
\hline & 0.688 & & 0.309 \\
\hline \multirow[t]{2}{*}{ Finance ${ }^{*}$ Recession } & -0.0226 & -0.0418 & \\
\hline & 0.134 & 0.013 & \\
\hline \multirow[t]{2}{*}{ Finance $*$ Condition } & -0.0409 & & -0.0430 \\
\hline & 0.000 & & 0.000 \\
\hline \multirow[t]{2}{*}{ Insurance*Recession } & -0.0174 & -0.0195 & \\
\hline & 0.012 & 0.008 & \\
\hline \multirow[t]{2}{*}{ Insurance* Condition } & -0.0045 & & -0.0058 \\
\hline & 0.275 & & 0.174 \\
\hline \multirow[t]{2}{*}{ Investment*Recession } & -0.0431 & -0.0462 & \\
\hline & 0.001 & 0.001 & \\
\hline \multirow[t]{2}{*}{ Investment ${ }^{*}$ Condition } & -0.0066 & & -0.0109 \\
\hline & 0.319 & & 0.117 \\
\hline \multirow[t]{2}{*}{ RealEstate*Recession } & -0.0021 & -0.0009 & \\
\hline & 0.890 & 0.952 & \\
\hline \multirow[t]{2}{*}{ RealEstate*Condition } & 0.0024 & & 0.0022 \\
\hline & 0.758 & & 0.773 \\
\hline \multirow[t]{2}{*}{ Services*Recession } & -0.0425 & -0.0520 & \\
\hline & 0.004 & 0.001 & \\
\hline \multirow[t]{2}{*}{ Services*Condition } & -0.0196 & & -0.0236 \\
\hline & 0.008 & & 0.002 \\
\hline Q2 Dummy & 0.0039 & 0.0039 & 0.0004 \\
\hline
\end{tabular}




\section{ROBUSTNESS AND AREAS OF FUTURE RESEARCH}

This section discusses some issues regarding the robustness of the presented results, ways in which the paper could be extended, and areas for future research.

The models presented here are based on those used in the literature. Accordingly, there are many complex variations that can be used as robustness checks for these results. Naturally, when determining which model to run and which variables to include, some variations are left out. Including more complex models may yield more robust estimates with higher explanatory power. ${ }^{8}$ For example, using alternative measures of profitability may show support for the results presented. In unreported regressions, Return on Assets (ROA) is used as the dependent variable in the models. The results are not substantially changed.

This study provides evidence supporting the hypothesis that financial firms are impacted more substantially by macroeconomic shocks using evidence on both profitability and stock return. However, many studies also focus on the speed at which macroeconomic news affects stock prices. Accordingly, different frequency data may be used to both add robustness to the results presented as well as to determine the more precise persistence of the effects.

Another way in which this study can be improved is to include a similar analysis using a sample of non-financial firms that may be affected by similar macroeconomic conditions. Financial sector firms are chosen because they are likely to be the firms most affected by the macroeconomic events affecting the financial markets. However, there are many other firms that also fit this category. For example, firms that pay large dividends, international firms and highly leveraged firms may also be more sensitive to macroeconomic shocks.

\footnotetext{
${ }^{8}$ For example, in an attempt to control for all business-cycle factors affecting firm profitability, we run unreported regressions using other independent variables, including the unemployment rate and the University of Michigan Consumer Sentiment Index. In all cases, the results for the financial distress factors are substantively unchanged.
} 


\section{CONCLUSION}

In the aftermath of one of the biggest financial collapses in recent history, it is natural to question the sensitivity of the financial sector to extreme macroeconomic distress. There are several ways to measure sensitivity. One line of literature looks at the stock price reaction surrounding economic news. Another focuses on how the macroeconomic regime affects the profitability of firms. This study expands the literature along these lines.

We utilize a combination of firm specific and macroeconomic variables to build a model of firm profitability and stock return performance. Using a robust series of univariate and multivariate techniques, it is shown that financial service firms are more sensitive to changes in financial stress than their real sector counterparts. We also find evidence that the impact of this sensitivity has increased over the past three decades.

The evidence that financial firms seem to be disproportionately affected by economic shocks contrasts starkly with the goals of many regulations imposed upon the industry. The financial services industry has historically been one of the most highly regulated industry sectors. The goal of most of these regulations is to provide confidence and stability in the financial system and avoid the economic disaster seen during the Great Depression. Over the past 30 years, however, relaxing regulations in the U.S. have allowed for the consolidation of financial service firms that are engaging in increasingly complex transactions. Additionally, there has been an increasing complexity in the financial services industry. The evidence pointing to increased systemic fragility in the financial sectors surrounding the recent financial crisis brings into question the soundness of these recent trends in regulation and financial product engineering. Indeed, our results support the idea that the source of financial sector firm risk lies in non-depository institutions and that this effect has increased in magnitude over time. Among these non-depository institutions, we focus on the contribution of insurance companies to these results. We find that insurance and real estate companies contribute less to this effect. We link the source of the pronounced impact of financial distress on financial institutions primarily to firms in the investment, finance and financial services industries. These results are consistent with the global financial market trends of globalization, deregulation and increasingly complex financial instruments. 


\section{REFERENCES}

Athanasoglou, P. P., Brissimis, S.N., and Delis, M.D., 2005. Bank Specific, Industry-Specific and Macroeconomic Determinants of Bank Profitability. Bank of Greece Working Paper 25.

Baur, D.G., 2012. Financial Contagion and the Real Economy. Journal of Banking \& Finance 36 (10).

Bernoth, K. and Pick, A., 2011. Forecasting the Fragility of the Banking and Insurance Sectors. Journal of Banking \& Finance 35, 807-818.

Bellas, D., Papaioannou, M., and Petrova, I.K., 2010. Determinants of Emerging Market Sovereign Bond Spreads: Fundamentals vs. Financial Stress. IMF Working Paper.

Blejer, M.I., 2006. Economic Growth and the Stability and Efficiency of the Financial Sector. Journal of Banking \& Finance 30, 3429-3432.

Bolt, W., de Hamm, L., Hoeberichts, M., van Oordt, M., and Swank, J., 2010. Bank Profitability During Recessions. DNB Working Paper No. 251.

Bomfim, A.N., 2000. Pre-Announcement Effects, News, and Volatility: Monetary Policy and the Stock Market. Working Paper.

Borensztein, E., and Lee, J., 2002. Financial crisis and the credit crunch in Korea: evidence from firm-level data. Journal of Monetary Economics 49, 853-875.

Chen, N., Roll, R., and Ross, S.A., 1986. Economic Forces and the Stock Market. Journal of Business 59(3), 383-403.

Claessens, S., Dell'Ariccia, G., Igan, D., and Laeven, L., 2010. Lessons and Policy Implications from the Global Financial Crisis.IMF Working Paper.

Clare, A., and Courtenay, R., 2001. Assessing the impact of macroeconomic news announcementson securities pricesunder different monetary policy regimes. Bank of England Working Paper.

Dietrich, A., and Wanzenried, G., 2010. Determinants of bank probability before and during the crisis: evidence from Switzerland. Working Paper.

Emir, O.Y.,Özatay, F., and Şahinbeyoğluc, G., 2005. Effects of U.S. Interest Rates and News on the Daily Interest Rates of a Highly Indebted Emerging Country: evidence from Turkey. CBRT Working Paper.

Ewing, B.T., 2002. Macroeconomic News and the Returns of Financial Companies.

Managerial and Decision Economics 23(8), 439-446. 
Fama, E.F., 1990. Stock Returns, Expected Returns, and Real Activity. Journal of Finance 45(4), 1089-1108.

Faust, J., Rogers, J., Wang, S., and Wright, J., 2003.The High-Frequency Response of Exchange Rates and Interest Rates to Macroeconomic Announcements.Board of Governors of the Federal Reserve System.International Finance Discussion Papers Number 784.

Flannery, M.J., and Protopapadakis, A., 2002. Macroeconomic Factors DO Influence Aggregate Stock Returns. The Review of Financial Studies 15 (3), 751-782.

Flannery, M.J., and James, C.M., 1984. The Effect of Interest Rate Changes on the Common Stock Returns of Financial Institutions. Journal of Finance 39(4), 1141-1153.

Frenkel, J.A., 1981. Flexible Exchange Rates, Prices, and the Role of "News": Lessons from the 1970s. Journal of Political Economy 89 (4), 665-705.

Funke, N., and Matsuda, A., 2006. Macroeconomic News and Stock Returns in the United States and Germany. German Economic Review 7(2), 189-210.

Hoffmann, P.S., 2011. Determinants of the Profitability of the U.S. Banking Industry.International Journal of Business and Social Science 2(22), 255-269.

Kutan, A.M., Muradoglu, G., and Sudjana, B.G., 2012.IMF Programs, financial and real sector performance, and the Asian crisis.Journal of Banking \& Finance 36, 164-182.

McQueen, G., and Roley, V.V., 1993. Stock Prices, News, and Business Conditions. Review of Financial Studies 6(3), 687-707.

Neely, C.J., and Dey, S.R., 2010. A Survey of Announcement Effects on Foreign Exchange Returns.Federal Reserve Bank of St. Louis Review 92(5), 417-4

Nijskens, R., and Wagner, W., 2011. Credit risk transfer activities and systemic risk: How banks became less risky individually but posed greater risks to the financial system at the same time. Journal of Banking \& Finance 35, 1391-1398.

Özatay, F., Özmenb, E., \&Şahinbeyoğluc, G., 2007.Emerging market sovereign spreads, Global financial conditions and U.S. macroeconomic news.ERF Conference.

Schwert, G.W., 1990. Stock Returns and the Real Activity: A Century of Evidence. Journal of Finance 45(4), 1237-1257

Shahbaz, M., AamirShamim, S.M., and Aamir, N., 2010. Macroeconomic Environment and Financial Sector's Performance: Econometric Evidence from Three Traditional Approaches. IUP Journal of Financial Economics 8, 103-123. 
Staikouras, S.K., 2005. Equity Returns of Financial Institutions and the pricing of interest rate Risk. Applied Financial Economics 15, 499-508.

Sufian, F., and Habibullah, M.S., 2010. Assessing the Impact of Financial Crisis on Bank Performance: Empirical Evidence from Indonesia. ASEAN Economic Bulletin 27(3), 245-262.

Williams, B., 2003. Domestic and international determinants of bank profits: foreign banks in Australia. Journal of Banking \& Finance 27, 1185-1210. 